\title{
Contribution and Division of Damages in Admiralty and Maritime Cases
}

\author{
Graydon S. Staring*
}

Contribution among joint tort-feasors has for many decades been said by courts to be the rule in admiralty. ${ }^{1}$ It has been understood at the Bar that the rule was general ${ }^{2}$ and there is little if any evidence of exceptions to the rule in the period between $1875^{3}$ and 1952 . In the latter year, however, in Halcyon Lines v. Haenn Ship Ceiling and Refitting Corp., ${ }^{4}$ an important exception was made which has raised doubt in the minds of some that the rule is one of general application at all.

In the Halcyon case a harbor worker injured aboard ship, being prohibited by the Longshoremen's and Harbor Worker's Compensation Act ${ }^{5}$ from sumg his employer, sued the shipowners instead. The shipowners impleaded the employer as a joint tort-feasor, praying for contribution. The Supreme Court denied contribution from the employer, pointing out that Congress had occupied the field and had not provided for contribution. In so holding the Court used very broad language: ${ }^{B}$

Where two vessels collide due to the fault of both, it is established admiralty doctrine that mutual wrongdoers shall share equally the damages sustained by each, as well as personal injury and property damage inflicted on innocent third parties. This maritine rule is of ancient origin and has been applied in many cases, but this Court has never expressly applied it to noncollision cases. Halcyon now urges us to extend it to non-collision cases.... ... To some extent courts exercising jurisdiction in maritine affairs have felt freer than common-law courts in fashioning rules, and we would feel free to do so here if wholly convinced that it would best serve the ends of justice.

We have concluded that it would be unwise to attempt to fashion new judicial rules of contribution and that the solution of this problem should await congressional action.

The Court's words have been considered by some lower courts to mean

* Member, San Francisco Bar.

1 Erie R.R. v. Erie \& Western Trans. Co., 204 U.S. 220 (1907); Barbarino v. Stanhope S.S. Co., 151 F.2d 553, 555, 1945 A.M.C. 1409, 1412 (2d Cir.): "[T]he suit is in the admiralty where contribution between joint tortfeasors has existed since 1875."

22 BENEDICT, ADMTRALTY 552 (6th ed. 1940).

3 See Barbarino v. Stanhope S.S. Co., 151 F.2d 553, 1945 A.M.C. 1409 (2d Cir.).

4342 U.S. 282, 1952 A.M.C. 1.

S 44 STAT. 1424 (1927), 33 U.S.C. $\$ \S 901-50$ (1952).

6 342 U.S. at 284-85, 1952 A.M.C. at 2-4. 
that there is no contribution in personal injury cases ${ }^{7}$ and by others to mean that contribution is restricted to collision cases exclusively. ${ }^{8}$ Either interpretation works a far-reaching change in American admiralty law and accordingly ought not to be adopted without a careful look at the entire background of contribution in admiralty. ${ }^{9}$ The occasion is accordingly presented for an historical survey of the development of contribution or division of damages and a careful analysis of the types of cases in which it is now applied.

\section{I}

\section{EARLY HISTORY OF CONTRIBUTION IN ADMIRALTY}

The history of contribution in admiralty is for the most part the history of the rule of division of damages, for which contribution is but another word. ${ }^{10}$ This rule, otherwise known as the moiety rule,,$^{11}$ the rusticum judi-

7 E.g., Union Sulphur and Oil Corp. v. W.J. Jones \& Son, Inc., 195 F.2d 93, 1952 A.M.C. 605 (9th Cir.) ; Hartford Acc. \& Indemnity Co. v. Gulf Refining Co., 127 F. Supp. 469, 1955 A.M.C. 197 (E.D.La. 1954), aff'd, 230 F.2d 346, 1956 A.M.C. 527 (5th Cir.), cert. denied, 352 U.S. 832 (1956).

8 Trygstad v. States Marine Corp., 150 F. Supp. 556, .............. ........ (D. Ore. 1957); Connors v. Brown S.S. Co., 115 F. Supp. 775, 1953 A.M.C. 1468 (W.D.N.Y.) ; see States S.S. Co. v. Rothschild Int'l Stevedoring Co., 205 F.2d 253, 1953 A.M.C. 1399 (9th Cir.); Allen v. States Marine Corp., 132 F. Supp. 146, 1955 A.M.C. 2235 (S.D.N.Y.); The Black Condor, 120 F. Supp. 865, 1954 A.M.C. 1631 (S.D.N.Y.) ; Davis v. American President Lines, 106 F. Supp. 729, 1952 A.M.C. 818 (N.D. Cal.); Esposito v. Pennsylvania R.R., 1952 A.M.C. 573 (E.D.N.Y.) ; McFall v. Compagnie Maritime Belge, 304 N.Y. 314, 107 N.E.2d 463, 1952 A.M.C. 1860. In Horan v. Pope \& Talbot, 115 F. Supp. 32, 33, 1953 A.M.C. 2157 (E.D.Pa. 1952), appears the statement that in the Halcyon case "it was held that under general maritine law no right of contribution exists as between joint tort-feasors." In The Black Condor, supra at 909, 1954 A.M.C. at 1632, appears the statement, "[T] he allegations of the impleading petition ... suggest a claim for contribution from a jomt tort-feasor-the type of claim disallowed in Halcyon . . . United States Gypsun Co. v. Curtis Bay Towing Co., 1953 A.M.C. 2071 (E.D. Va.), also contains an implication that, following Halcyon, contribution would no longer be available in collision cases. These extreme expressions are regarded as inadvertent and not to be taken seriously.

9 It is not the author's purpose to challenge the decision in the Halcyon case. Although the opmion of the Supreme Court is confusing, the true grounds for the decision are to be found in American Mutual Liability Ins. Co. v. Matthews, 182 F.2d 322, 1950 A.M.C. 1272 (2d Cir.), where it is pointed out that contribution in adiniralty, as distinct fron contribution at law, arises directly from the tort rather than circuitously upon a theory of subrogation and that since under the Longshoremen's Act the employer is not a tortfeasor, he is not hable for contribution. The analytical shortcomings of Halcyon have been fully covered by other writers. E.g., 21 Geo. Wast. L. Rev. 241 (1952), 6 MIAMI L.Q. 606 (1952), 1952 U.C.L.A. Intra. L. REv. 23.

10 The Mariska, 107 Fed. 989 (7th Cir. 1901) ; The Hudson, 15 Fed. 162 (S.D.N.Y. 1883); The Cairnbahn, [1913] 12 Mar. L. Cas. (n.s.) 455 (C.A.) ; accord, The Perth Amboy No. 2, 110 F.2d 644, 1940 A.M.C. 621 (2d Cir.); Louis-Dreyfuss v. Seaboard Great Lakes Corp., 69 F.2d 71, 1934 A.M.C. 215 (2d Cir.); The Cherokee, 45 F.2d 150, 1930 A.M.C. 1957 (2d Cir.); see The Ira M. Hedges, 218 U.S. 264 (1910) ; Erie R.R. v. Erie \& Western Transp. Co., 204 U.S. 220 (1907); The Frankland, [1901] 9 Mar. L. Cas. (n.s.) 196. The North Star, 106 U.S. 17 
cium $^{12}$ or judicium rusticorum, ${ }^{13}$ is of ancient origin. The rule can readily be traced to the thirteenth century and there is no reason to suppose it to have been an innovation then. It appears to have governed certain distinctly non-maritime matters in Biblical times, ${ }^{14}$ and, by analogy to the precepts of Moses, it may well have been applied to ship collisions in the centuries before it first appeared in the early martime codes.

The first evidence of the rusticum judicium as a positive enactment appears in the Laws of Oleron which are considered to date from the twelfth century. ${ }^{15}$ This code is supposed to have been applied by the English Admiralty at an early date and its provision is therefore of most interest to us as the one from which our present law may be presumed to have evolved. ${ }^{10}$ Under article XIV of the Laws of Oleron, ${ }^{17}$ division was provided for damage to a ship at anchor struck by one under way. The loss, presumably of the anchored vessel only, was to be divided equally between the owners of the two ships, provided the master and mariners of the ship under way swore that the damage was done accidentally and not willingly. Apart from this oath, fault had nothing to do with liability. The character of the rule as a mere risk sharing device not founded on considerations of fault is shown by the further provision that damage to cargo should be divided equally between the cargo owners of the two vessels.

A rule, in some form, for division of damages appears not only in the

(1882), a leading case on division of damages, is referred to as a contribution case by the Supreme Court in the Halcyon case.

11 The rule does not limit itself to moieties but extends to a division into as many parts as there are parties at fault. Thus, thirds damages, fourths damages, etc., may be spoken of.

12 "Rude judgment." This term arose before division of damages depended on mutual fault.

13 This term is used by Cleirac and by Chancellor Kent. CLeIRAC, Us ex Coustomes de IA Mer (1616); 3 Kent's CoMamentarIEs 184 (1828). It appears to be a derisive variation of the term which precedes it. Cleirac compared the rule to Solomon's judgment between the two mothers.

14 Exodus xxi, 35-36: "And if one man's ox hurt another's, that he die; then they shall sell the live ox, and divide the money of it; and the dead ox also they shall divide. Or if it be known that the ox hath used to push in time past, and his owner hath not kept him in; he shall surely pay ox for $0 x$; and the dead shall be his own."

151 Pardessus, Coliection des Lois Marutimes 283-322 (1828).

${ }^{16} \mathrm{La}$ Ley Oleyroun is referred to as the law of the English admiralty in the roll De Superioritate Maris et Jure Adnirahtatis Anghiae of 12 EDw. 3 (1338). I BLACK BooK OF THE ADMIRALTY (ROLIS SER. 1871).

17 Article XIV of the Laws of Oleron, as found in 30 Fed. Cas. 1171, 1178 (1897), reads as follows: "If a vessel, being moored, lying at anchor, be struck or grappled with another vessel under sail, that is not very well steered, whereby the vessel at anchor is prejudiced, as also wines, or other merchandize in each of the said ships damnified. In this case the whole damage shall be in common, and be equally divided and appraised half by half; and the master and mariners of the vessel that struck or grappled with the other, shall be bound to swear on the Holy Evangelists, that they did it not willingly or wilfully. The reason why this judgment was first given, being, that an old decayed vessel might not purposely be put in the way of a better, which will the rather be prevented when they know that the damage must be divided." 
Laws of Oleron, but also in the other northern European codes, ${ }^{18}$ in the Ordonnance of Louis XIV, ${ }^{19}$ in the south European code Consolato del Mare, ${ }^{20}$ and even in codes in force in the Orient. ${ }^{21}$ The exact provisions of these several codes varied widely. Most covered only collisions between an anchored vessel and one under way; such were the provisions in the Laws of Oleron and of Wisby-the presumptive antecedents of our own law of division. Some codes, however, also divided damages when both ships were under way; ${ }^{22}$ at least one divided loss on one basis where both ships were under way and on another basis where one was anchored; ${ }^{23}$ still others applied specifically to cases of lost anchors or damage from anchors to other vessels. ${ }^{24}$

Certain of the codes provided that the damaged vessel should recover one-third ${ }^{25}$ or two-thirds ${ }^{26}$ of her damages in particular instances. In some cases the division was to be in a proportion to be determined by arbitrators; ${ }^{27}$ in those cases it seems that fault must have been taken into consideration at a practical level, if not by positive rule. For the most part, however, the early codes stated simply that damage was to be divided, and neglected to say that the division was to be equal, although there has been very litle doubt that it was. ${ }^{28}$

Since the Laws of Oleron were known in England and recognized as authoritative in the fourteenth century, the rusticum judicium was presum-

18 Such provisions appear in the codes of Bruges, 4 BLACK Book of THE ADMIIRALTX 435 (Rolrs Ser. 1876) ; Damme, 1 Pardessus, Collectron des Lois Maritrares 379 (1828); Danzig, 4 Black Book of the Adarralty 349 (Rolis Ser. 1876) ; Denmark, 3 Pardessus, ColIECTION DES LOIS MARTTIMES 237, 261, 289 (1834) (codes of 1508, 1561, and 1683); Hamburg, 3 id. 345, 348; The Hanse Towns, 2 id. 551 (1831); 30 Fed. Cas. 1197 (1897); Lubeck, 3 PARdessus, Collection des Lois Maritmies 402 (1834); 4 Black Book of the AdMIRaity 373 (Rolts Ser. 1876); The Netherlands, 4 Pardessus, Collectron des Lors Maritrures 34, 85 (1837); Riga, 3 id. 506 (1834); Sweden, 3 id. 129, 173; and Wisby, I id. 501 (1828); 3 id. 114 (1834); 4 BLACK Book of tHE ADMIRALTY 87, 125, 284 (1876); 30 Fed. Cas. 1189-95 (1897).

192 Varin, Nouveau Contarentatre Sur L'Ordonnance de la Marine 178 (1766); 30 Fed. Cas. 1203, 1215 (1897).

202 Pardessus, Collection des Lois Marttrmes 174 (1831).

21 E.g., Malacca, 6 id. 409, 459 (1845).

22 E.g., Denmark, Ordonnance of Louis XIV.

23 Denmark (Ship underway paid one-third loss to ship at anchor; where both underway, ratio was determined by arbitrators.). 3 Pardessus, Colfection des Lors Maritmmes 237, 261, 289 (1876).

24 Hanse Towns, 2 id. 551 (1831); Netherlands, 4 id. 34, 85 (1837); Wisby, 1 id. 501 (1928); 3 id. 114 (1834) ; 4 BLACK BOOK OF THE ADMTRAITY 87, 125, 284 (1876); 30 Fed. Cas. $1189-95$ (1897).

25 Denmark, 3 Pardessus, Cortection des Lois Martimies 237, 261, 289 (1876); Sweden, 3 id. 129, 173; Mallaca, 6 id. 409, 459 (1945).

26 See 6 Pardessus, Coltection des Lois MartTimes 409, 459 (1845).

27 Denmark (both ships underway), Consolto del Mare.

28 See note 19 supra. Valin also notes that an opmion was held that division should be in proportion to value, like general average. Such a view emphasizes the risk-sharing basis of the early rule. 2 Valin, Nouveau CoMamentaIRe SUr L'OrdonNance de la Marine 178 (1766). 
ably applied by the English Admiralty in that period. The continuous series of admiralty court records does not begin, however, until about the year 1530 and so there is no definite evidence of the application of the rule in the English Admiralty prior to that time; nor is there any trace of the rule in any existing sentence of the court during the sixteenth century..$^{20}$ Mars$\operatorname{den}^{30}$ has reviewed the early admiralty records and he concludes that the English judges, while they applied the rule in accordance with the early codes, were at a loss after concepts of negligence arose to find reasons for applying the rule when negligence was proved against one or both ships. Negligence or fault had had little if anything to do with the ancient moiety rule, and when negligence was actually proved it must have seemed to the judges that the rule was no longer useful. Thus contribution barely survived to pass into modern jurisprudence; in the process it was transformed by modern notions of negligence or fault.

The first sentence for half damages, of which there is presently any record in the English Admiralty, occurs in 1614, and it is apparent that the ancient rule was being followed, for the case was one of sole fault. ${ }^{31}$ During the next 30 years there were repeated applications of the rusticum judicium to the sole fault situation, but there also appear in this period a number of cases in which full damages were recovered. No explanation is given by the court for the decisions in either line of cases, nor is there any basis for distinguishing the one from the other. While it may be thought that the court is sometimes applying the rule of division and sometimes iguoring it, it is well to remember that the rule had its exceptions; it is entirely possible that the cases in which full damages were awarded fell within the exceptions. Under the Laws of Oleron the division of damages was achieved only by a kind of wager of law in which the master and the mariners of the vessel swore upon the Holy Evangelists that they did not strike the other vessel willingly (de bon gre). Difficult as it may be to conceive of in the present age of impiety, the failure of the court to divide damages in some cases may be due to the reluctance of the masters and mariners on the losing side to take their oaths.

In the 1640's there begins a period of apparent soul-searching by the judges of the Enghish Admiralty which was very likely caused by the development of negligence concepts. In a number of sentences for divided damages occurring in this decade findings of negligence ${ }^{32}$ have been originally written in and then crossed out as though perhaps inconsistent with

29 MARSDEN, Colirisions 138 (10th ed. 1953).

30 Id. at 152 .

31 The material on early records of the English Admiralty Court in the text beginning at note 31 is entirely from MARSDEN, Colisions 139-49 (10th ed. 1953).

32 "per crassam suam negligentiam"; "incuria et negligentia"; "incuria." 
the moiety rule. In three cases in this period, the court divided the damages unequally, curiously indicating that it had reasons for so doing but declining to be more specific. In this same decade occurred the first case in which half damages are given expressly because the cause of the loss was uncertain. And throughout the decade, as before, sentences of full damages are occasionally given.

From 1650 to 1746 a fairly consistent practice appears. Wherever a defendant was expressly found in sole fault the sentence was for full damages, as it would be today. Wherever, as in a considerable number of cases in this period, the collision was accidental (casu fortuito) or the cause uncertain by reason of contrariety of witnesses and difficulty of proof, damages were divided. Finally, when both ships were found at fault, damages were likewise divided. There are, as usual, a number of cases in which no reasons for the results are given, and there are also a few anomalies such as a dismissal for failure to prove fault and a decree of half damages on the ground that the sole fault of the defendant was not willful, which is inconsistent with other cases showing that negligence was sufficient to constitute fault warranting a sentence of full damages.

During this century, in 1675, the modern mechanics of the half damages rule appear, the judge having decreed, in a case of collision from uncertain cause, that the ship with least damage pay the other vessel one-half the balance of the loss. In another case of special interest, in 1706, the court appeared to have the philosophical desirability of the comparative negligence rule in mind when it decreed an equal division, as was usual in mutual fault, and apologized, explaining that it did so because of the difficulty of proving the loss attributable to each ship. Between 1746 and 1789 no instance of division of damages appears but in 1788 there occurred a case in which division was presumably considered, and it was held that "under the circumstances of the case, each party should stand by his own damage and expenses." ${ }^{\prime 3}$ In the remaining years of the eighteenth century there occurred several instances of division for mutual fault, in one of which there was an express finding that one ship was more at fault than the other. In 1789 the Admiralty judge very deliberately announced a short lived doctrine that division of damages was the rule in case of inevitable accident due to darkness and stress of weather.

In 1815 Lord Stowell (then Sir William Scott) in The Woodrop-Sims ${ }^{34}$ delivered a dictum, which has since become famous, in which he divided collisions into four classes: (1) sole fault of the defendant ship; (2) sole fault of the plaintiff ship; (3) fault of both ships; and (4) without fault

33 MarSDEN, Collisions 146 (10th ed. 1953).

342 Dods. 83, 165 Eng. Rep. 1422 (1815). 
on either ship. He declared that the rule of division of damages was applicable only where both ships were at fault. Lord Stowell's dictum was strengthened when it was cited by the House of Lords in Hay v. LeNeve, ${ }^{36}$ where a Scottish court had apportioned damages unequally and the House of Lords divided them equally.

The rule laid down by Lord Stowell in The Woodrop-Sims and the House of Lords in Hay v. LeNeve remained the law in England until the Maritime Conventions $\mathrm{Act}^{\mathrm{36}}$ established the comparative negligence rule of unequal apportionment. The effect of Lord Stowell's dictum was to overrule the older authorities which held that division applied to cases of collision without fault or by inevitable accident and to cases in which it was impossible to establish the cause-cases which today in America would be described as cases of inevitable accident or inscrutable fault. The rule in America as to such cases was left in doubt longer and may still be in doubt as to inscrutable fault today.

\section{II}

DEVELOPMENT OF THE RULE IN AMERICA

\section{A. Collision Cases}

Mutual fault-vessels in collision

There is no report of any court statement of the moiety rule in America earlier than 1836 although text writers stated the rule earlier. The lawyers of the Colonies and the young republic were well aware of the main current of English decisions and, at least in such ports as New York and Boston, must have been familiar with division of damages. If the rule was not applied with regularity, it would not be surprising, considering the lack of constancy shown even in England prior to Lord Stowell's dictum of 1815. In early America, moreover, many collision actions were undoubtedly brought in state courts and it was then, and for some time after, thought that the common law rules applied to maritime actions in common law courts. ${ }^{37}$

In 1818 Jacobsen's Laws of the Sea, a German text, published in translation in Baltimore, announced the rule of division in collision cases: ${ }^{38}$

If the damage is done reciprocally, such damage is apportioned in common, between the parties.

\footnotetext{
352 Shaw Scotch App. 395 (1824).

361 \& 2 Geo. 5 , c. 57 (1911).

${ }^{37}$ See, e.g., Belden v. Chase, 150 U.S. 674, 691 (1893) (dictum).

38 JACOBSEN, LAWS OF TEE SEA 328 (1818).
} 
Chancellor Kent stated the rule in $1828^{39}$ and Justice Story in $1832^{40}$ repeated the rule as stated by Lord Stowell. In The States Rights, ${ }^{41}$ in 1836, Jacobsen's Laws of the Sea was cited for the proposition that damages were divided in cases of mutual fault. The court, however, determined that only one ship was at fault and hence found division inapplicable.

By 1843 the rule of division had been noticed by the Supreme Court. In The Louisville, ${ }^{42}$ a case of sole fault, the Court stated as dictum Lord Stowell's four cases of collision. In 1854 the Supreme Court was first presented with a mutual fault case and squarely faced with the necessity of adopting or rejecting a rule of division of damages. In adopting the rule the Court said: ${ }^{43}$

[I] $t$ becomes necessary to settle the rule of damages in a case where both vessels are in fault.

The question, we believe, has never until now come distinctly before the court for decision. The rule that prevails in the district and circuit courts, we understand, has been to divide the loss .... This seems to be the wellsettled rule in the English admiralty ....

Under the circumstances usually attending these disasters, we think the rule dividing the loss the most just and equitable, and as best tending to induce care and vigilance on both sides, in the navigation.

The propriety of division received no further amplification from the Supreme Court. The next two cases in which decrees for division came before it on appeal were affirmed without comment on the moiety rule. ${ }^{44}$

While the cases hitherto decided had been cases of negligent fault, there shortly came before the Court The R. L. Mabey, ${ }^{45}$ in whicli the lower court had denied all recovery upon the ground that the faults on both sides had been willful. The Supreme Court reversed upon finding that the case was not one of willful fault, but intimated that had it been such a case the loss would lie where it fell: ${ }^{46}$

Cases may occur in which two steainboats engaged in unlawful racing may recklessly or willfully dash against each other; and the courts, treating them both as criminals, may refuse to sustain an action or decide which was most to blame, leaving each to suffer the consequences of his own folly and recklessness.

We do not think that the testimony shows this to be such a case.

\footnotetext{
893 Kent, Conatentaries 184 (1828).

40 Story, Batmant §608 (1832). Aвbot, Shmping (2d Am. ed., notes by Story 1810) makes no mention of the rule.

4120 Fed. Cas. 201, 208, No. 11540 (E.D. Pa. 1836).

4242 U.S. (1 How.) 89, 92 (1843).

43 The Catherine, 58 U.S. (17 How.) 169, 177 (1854).

44 The Autocrat, 59 U.S. (18 How.) 463 (1855); The Ogdensburgh, 62 U.S. (21 How.) 548

4562 U.S. (21 How.) 451 (1859).

46 Id. at 453 .
} (1858). 
In the earliest cases both ships had been damaged and both were before the Court. It was usual to state that the damages of the two should be added and divided by two. This gave rise to the contention that where but one vessel was libeled it was necessary for the court to inquire into the damages to the other vessel in order to comply with the rule as to computation of damages. The Supreme Court put that notion to rest in 1873, pointing out that the decree in such a case is for one-half the damages suffered and that where a vessel and her owners are not sued her damages are not before the court. ${ }^{4 \pi}$

Where, however, only one of two vessels at fault in damaging a third is sued, the result is different. In each of two cases decided by the Supreme Court in 1876, The Atlas ${ }^{48}$ and The Juniata, ${ }^{40}$ innocent barges and their cargoes were sunk by the combined faults of two other vessels. In one case the barge owner and in the other the cargo owner sued only one of the vessels at fault. The Court held that, notwithstanding mutual fault such that damages would have been divided had both vessels been before the Court, the innocent victim was entitled to a full recovery from the single wrongdoer he had chosen to sue. In both cases the Court intimated, however, that the shipowners might recover from the other vessels at fault by appropriate proceedings. In another case of this period, ${ }^{50}$ in which only one party had suffered damage, the Supreme Court clearly identified contribution or division as the rule applicable to the simple case of joint fault of a libelant and respondent when there was no cross-libel, despite the use of such a typically common-law expression as "contributory negligence." The same contributory negligence which defeated recovery at common law, said the court, in admiralty only resulted in the application of the admiralty rule of division.

In 1883 Judge Addison Brown, who contributed so much to American maritime law, rendered a notable decision which enunciated the nature and force of contribution in terms which very shortly received an unusual tribute from the Supreme Court. In The Hudson, ${ }^{51}$ the New York district court had before it a libel by barge owners against the Hudson for collision. The owners of respondent Hudson sought to implead the tug E. A. Packer, which had been towing the barge, as equally to blame and equally liable. At this time there was neither rule nor precedent for impleader in admiralty, but Judge Brown allowed it, saying: ${ }^{52}$

47 The Sapphire, 85 U.S. (18 Wall.) 51 (1873).

4893 U.S. 302 (1876).

4093 U.S. 337 (1876).

50 Atlee v. Packet Co., 88 U.S. (21 Wall.) 389 (1874).

5115 Fed. 162 (S.D.N.Y. 1883). The Hudson was adopted in The Mariska, 107 Fed. 989 (7th Cir. 1901).

6215 Fed. at $165-66$. 
These cases show how firmly established in this country, by the highest authority, is the legal right in admiralty of the several vessels, liable for the same collision, to have the entire loss and damages apportioned equally among them, so far as such an apportionment can be made without injury to the libelant, whenever the parties are before the court, or whenever there is any fund which the court can lay hold of and make tributary to such an apportionment. The right of contribution is thus affirmed, it seems to me, as a substantial legal right, and as such it is entitled to all appropriate and expedient remedies. In effect, while the libelant has a martime lien upon each vessel in solido for his whole damage, so that both are liable jointly and severally as principals, yet, as between themselves, the several vessels liable are virtually in the situation of sureties for each other for the payment by each of one-half the damages; and each vessel, like other sureties in equity, lias such a legal interest in the libelant's enforcement of his lien upon the other, that the court must by its decree carefully protect this interest whenever the parties are before it, and on failure to do so its decree will be reversed.

From this well-settled recognition and enforcement of a right of contribution as a substantial legal right, when the parties are before the court, it would seem to result necessarily that if only one vessel is sued, where another is equally liable, either an independent suit for contribution must be allowed to the latter, or else the other vessel must be brought into the original cause, if that can be done without any substantial injury to the libelant. It would be a gross anomaly to say that the court must, by its decree, recognize and enforce a riglit of apportionment between several vessels defendant, if they all happen to be parties, but yet lias no power to bring in one of them if absent, or to afford a several remedy against it. If the right of contribution depended wholly upon the libelant's happening to sue both vessels instead of one, instead of being a legal right it would be but a mere accident in the cause, dependent solely upon the libelant's option.

The Hudson was an outstanding example of constructive rule-making in the best tradition of the admiralty. The Supreme Court quickly recognized the value and essential justice of the rule and made it umiform throughout the country six weeks later by adding it to the Rules of Practice in Admiralty and Maritime Cases. ${ }^{53}$ The time was now ripe to test the implications of The Atlas and The Juniata ${ }^{54}$ and to try out the possibility of collecting contribution by a separate suit in admiralty.

When the steamers New York and Conemaugh collided in the Detroit River one night in 1891 they set up such a wave of litigation as should evermore be a solemn warning to navigators tempted to neglect their lookout. The owners of the Conemaugh libeled the New York on behalf of certain of the Conemaugh's cargo owners as well as themselves. The underwriters of other cargo on the Conemaugh intervened against the New York. The claimants of the New York filed a cross bibel against the Conemaugh for

53 The rule is now Fed. R. AdariraIty Prac. 56.

54 See text at notes 48 and 49 supra. 
the New York's damage but did not implead the Conemaugh or claim contribution in their cross libel for any damages they might have to pay to the owners of Conemaugh cargo. The case went to the Supreme Court on the issue of fault, which was held to be mutual. ${ }^{55}$

In the district court, upon the mandate of the Supreme Court, a decree was entered granting Conemaugh cargo owners their full recovery against the New York and dividing the damages of the two vessels equally between them. Since the Conemaugh had suffered the greater damage the effect was to require a payment to her from the New York. The New York contended that she was entitled to recoup out of her payment to the Conemaugh onehalf of the damages decreed against her in favor of Conemaugh cargo owners. Recoupment was demed her in the decree.

The New York's owners sought their remedy in the Supreme Court by petition for a writ of mandamus, but were told by the court that their remedy lay in appeal. ${ }^{56}$ Remanded to the circuit court of appeals, in time they again sought their remedy in the Supreme Court, this time by certiorari. The court held that notwithstanding that all parties were before the lower court, yet the issues were governed by the pleadings, and the New York, having never claimed for contribution either in her cross libel or by impleader, was foreclosed in this action. The court did, however, suggest a further action: ${ }^{57}$

The New York, having been in fault, was responsible to the cargo, and if, as between her and the Conemaugh, she have a claim for recoupment, the way is open to recover it.

The owners of the New York were not slow to take the hint and eventually arrived once more in the Supreme Court with an in personam decree from an admiralty court against the owners of the Conemaugh for contribution. A unanimous Court upheld their decree and rejected the contention that the admiralty court was without jurisdiction of such an action. ${ }^{68}$ Speaking for the Court, Mr. Justice Holmes said: ${ }^{50}$

If it be assumed that the right to contribution is an incident of the joint liability in admiralty ... it would be a mere historical anomaly if the admiralty courts were not free to work out their own system and to finish the adjustment of maritime rights and habilities.... It cannot be that because the admiralty has carried out a part of its theory of justice, it is prevented by that fact alone from carrying out the rest.

With this decision the main outline of contribution was complete. It was of the substance of our maritime law. It could be obtained as division where

\footnotetext{
55 The New York, 175 U.S. 187 (1899).

56 Ex parte Union Steamboat Co., 178 U.S. 317 (1900).

57 The Conemaugh, 189 U.S. 363, 367-68 (1903).

58 Erie R.R. v. Erie \& Western Transp. Co., 204 U.S. 220 (1907).

59 Id. at 225 .
} 
both parties were before the court; where one party was not before the court he could be impleaded; and finally, contribution could be sought in a separate action of which the admiralty had jurisdiction.

\section{Mutual fault-toreing vessels not in collision}

If there were any doubts in America in the nineteenth century, as there were in England, ${ }^{60}$ about the application of the rule of contribution to vessels at fault but not actually in collision, they had been resolved by 1875 when in The Alabama and The Gamecock ${ }^{61}$ the Supreme Court granted contribution from the towing vessel, not in collision, for damage to the innocent tow, evidently without considering the question open.

The mode of division where more than two vessels were at fault remained an open question for some time thereafter. Should two or more barges lashed together be treated as one vessel or as several for the purpose of dividing damages? Did it make any difference whether two or more of the vessels at fault belonged to the same owner? ${ }^{22}$ These questions were answered by the Supreme Court, on certificate, in The Eugene F. Moran. ${ }^{63}$ The Moran was towing two scows, $15 \mathrm{D}$ and $18 \mathrm{D}$. The $15 \mathrm{D}$ collided with a carfloat in tow of the tug Charles E. Matthews through the mutual fault of the Moran, the 15D, the 18D and the Matthews. The 15D and 18D belonged to the same owner. The owner of the carfloat libeled all the other vessels and the Court held that the damages to the carfloat should be divided equally among all the guilty vessels, notwithstanding common ownership of the 15D and 18D and their being bound together in a flotilla. In a separate action the owner of the $15 \mathrm{D}$ had libeled the Moran and the Matthews. The question there was how to divide damage considering that the $18 \mathrm{D}$, having the same owner as the $15 \mathrm{D}$ and being one of the vessels at fault, was not a party. The Court held that the libelant, owner of two of the four guilty vessels, should bear two shares or one-half of the total damage to the $15 \mathrm{D}$, stating that the convement fiction by which vessels are personified for security should not be extended so as to lessen the liability of an owner

60 In England it does not appear to have been established until 1894 that the non-towing vessel sued by the tow could obtain contribution from the tug. But in that year contribution was allowed in The Englishman and Australia, [1894] 7 Mar. L. Cas. (n.s.) 603, 605: "The one point which introduces a new element for consideration is that though one of the two ships in collision was the ship of the plaintiffs, the other ship in collision was not the ship of the defendants. But this appears to ine to be immaterial when once it is established that the defendants are liable in respect of this collision, and that their hability rests on a principle forming part of the law maritime...."

0192 U.S. 695 (1875); accord, The Virginia Ehrman, 97 U.S. 309 (1877).

02 In The Bellingham, 138 Fed. 619 (W.D. Wash. 1905), two steamers of common ownership, the Bellingham and the Dode, while lashed together and powered by the Bellingham, collided with another through the fault of all three, and the court considered the Bellingham and Dode as one vessel bearing together one-half the damages.

63212 U.S. 466 (1909). 
because of the accident that one of his guilty vessels was not before the court..$^{\text {64 }}$

[T] he quantum of liability ought not to be affected by the position of the party concerned as codefendant or plaintiff, and the rule of equal division among the guilty vessels has prevailed, in some cases, at least, as well when one of them was the libellant as when they were all on the same side.

The Court held that the vessels were to be taken singly rather than by flotillas and without regard for ownership.

An additional feature of The Eugene $F$. Moran and the later case of The Ira M. Hedges ${ }^{65}$ is that contribution was allowed between parties having contract relations, in those cases the owners of the tows and the owners of the tugs. ${ }^{68}$

\section{Mutual fault-ship and bridge or other fixed object}

Although the striking of a fixed object by a ship is not precisely "collision, ${ }^{\prime 67}$ no distinction has been made between such a case and a case of true collision except as necessary for jurisdictional considerations. ${ }^{68}$ When a Mississippi River steamer, negligently navigated, struck a pier which constituted an unlawful obstruction and sued the owner of the pier, the Supreme Court divided the steamer's damages, using language which showed that no distinction existed between the concept of division of damages in an ordinary collision case and the rule to be applied wherever contributory negligence was found in the party suing: ${ }^{69}$

e4 212 U.S. at 476.

65218 U.S. 264 (1910).

${ }^{68}$ In The White City, 285 U.S. 195, 1932 A.M.C. 468, it was said that the liability of a tug to her tow for negligent navigation is ex delictu and not ex contractu. Certainly this is so where there is no contract between the owners of the tug and the owners of the tow. But where a contract exists the statement becomes a little strained, particularly when we realize the possibilities for varying or specifying the liabilities by express terms. In such a case the statement probably should be regarded as meaning no more than that a towage contract implies an obligation of due care and that the obligation will be measured by ordinary tort standards.

67 The technical term is "allision."

68 The owners of a vessel in collision with a bridge could always sue the bridge owners in admiralty and obtain division of damages in case of contributory negligence. Atlee v. Packet Co., 88 U.S. (21 Wall.) 389 (1874) (pier); see cases cited at note 70 infra. But for a century and a lalf, while the admiralty courts generally refrained from exercising their jurisdiction over injuries by vessels to land objects, the bridge owners were obhiged to sue at law, where their contributory negligence barred them from any recovery. The Kearney, 14 F.2d 949, 1926 A.M.C. 1640 ( $3 \mathrm{~d} \mathrm{Cir}$.). This most unsatisfactory situation was brought to an end with the passage of the Extension of Admiralty Jurisdiction Act of 1948, 62 STAT. 496,46 U.S.C. $\$ 740$ (1952), by which the district courts were directed to exercise their admiralty jurisdiction over injuries done by vessels and consummated on land. See United States v. Matson Nav. Co., 201 F.2d 610, 1953 A.M.C. 272 (9th Cir.). Since the bridge may now sue in admiralty, the effect of contributory negligence is now uniform regardless of who sues. If the bridge sues at law, its right to division of damages, being a right in admiralty, will be enforced at law. See text at note 222 infra.

${ }^{69}$ Atlee v. Packet Co., 88 U.S. (21 Wall.) 389, 395 (1874). 
In the common law court the defendant must pay all the damages or none. If there has been on the part of plaintiffs such carelessness or want of skill as the common law would esteem to be contributory negligence, they can recover nothing. By the rule of the admiralty court, where there has been such contributory negligence, or in other words, where both have been in fault, the entire damages resulting from the collision must be equally divided between the parties.

While most of this class of cases arise from striking bridges, ${ }^{70}$ either because of some defect in their construction or shortcoming in their maintenance or, in the case of draw bridges, because of some negligence in the operation of the draw, the same result obtains where a ship strikes a breakwater under construction and not properly lighted; ${ }^{71}$ a submerged rock or other obstruction which another has a duty to remove; ${ }^{72}$ or even a net inadequately marked. ${ }^{73}$ Under the Wreck Statute ${ }^{74}$ a duty is imposed upon shipowners to mark the wrecks of their ships. Where the buoy used to mark a wreck was so misplaced as to mislead another craft, also at fault, into striking the wreck, damages were divided between the vessel owner and the party under a duty to mark the wreck. ${ }^{75}$ And a vessel fouling a submarine cable with her anchor divides damages with the cable owner where the fault is mutual. ${ }^{76}$

At least one interesting problem still lurks in this area: the question of whether and how to apply division of damages in connection with the provisions of the Rivers and Harbors Act ${ }^{77}$ in the rare case where there might be inutual fault in connection with damage to one of the works, structures, or floating plants protected by that act. The act provides for absolute liability in rem, on the part of any vessel used or employed in injuring any of the protected objects, not only for the damages but for a penalty as well. ${ }^{78}$ Assuming the injury to be actually caused in whole or in part by the Government, the question arises whether this will affect the damages. Three choices are presented: (1) The dainages may be divided as in ordinary

70 Louis-Dreyfuss v. Seaboard Great Lakes Corp., 69 F.2d 71, 1934 A.M.C. 215 (2d Cir.) Smith v. City of Shakopee, 103 Fed. 240 (8th Cir. 1900); The Gramercy, 87 F. Supp. 132 (D.N.J. 1949); United States v. Norfolk-Berkeley Bridge Corp., 29 F.2d 115, 1928 A.M.C. 1636 (E.D. Va.); see The Robert Johnson, 72 F.2d 712, 1935 A.M.C. 189 (9th Cir. 1934); M \& M Dredging \& Constr. Co. v. Miami Bridge Co., 39 F. Supp. 311, 1941 A.M.C. 1661 (S.D. Fla.).

71 Harrison v. Hughes, 110 Fed. 545 (D. Del. 1901), aff'd 125 Fed. 860 (3d Cir.), cert. denied, 191 U.S. 575 (1903).

72 The Robaliss III, 48 F.2d 701, 1931 A.M.C. 906 (2d Cir.) ; see Gulf Atlantic Transp. Co. v. Becker County Sand \& Gravel Co., 122 F. Supp. 13, 1955 A.M.C. 128 (E.D.N.C. 1954).

73 The Beatrice and Rose, 84 F. Supp. 761, 1950 A.M.C. 665 (D. Me. 1949).

7430 STAT. 1152 (1899), 33 U.S.C. \$ 409 (1952).

70 Somerset Seafood Co. v. United States, 193 F.2d 631, 1952 A.M.C. 697 (4th Cir. 1951).

70 The Godafoss, 129 F. Supp. 657, 1955 A.M.C. 755 (D. Mass.).

7730 STAT. 1152 (1899), 33 U.S.C. $\$$ 408, 411, 412 (1952).

78 The Scow "G-S", 250 U.S. 269 (1919). 
cases of mutual fault; (2) the Government may recover its damages in full while the offending vessel recovers nothing; or (3) the Government may recover its damages in full and the offending vessel may recover either all or half its damages according to whether the Government is wholly or only partly at fault. Division as in ordinary cases would seem inappropriate as in conflict with the statute's provision that the Government have its "damages"; the conclusion that this means all its damages is fortified by the penalty provision. The second course seems likewise inappropriate because nothing in the statute purports to deprive the private vessel owner of his ordinary right to recover his damages for fault on the part of the Government. It is submitted that the third course is the correct one and that the Government's damage is to be considered under the provisions of this act and the damage to the private vessel disposed of upon ordinary principles unaffected by the act.

\section{Inevitable accident and inscrutable fault}

As we have seen, divided damages had its roots in mevitable accident and, more particularly, inscrutable fault, rather than mutual fault. When it acquired a new rationale in connection with mutual fault, its continued application was questioned, by a strange turn of thought, in the very cases from which it arose.

Lord Stowell in The Woodrop-Sims ${ }^{70}$ had laid down the law in England to be that there was no division in a case of inevitable accident, but he had not inentioned what we now know as inscrutable fault. In America Chancellor Kent stated that division was the rule in mutual and inscrutable fault: ${ }^{80}$

The rule is universally declared by all the foreign ordinances and jurists; and its equity and expediency apply equally where both parties are to blame, and where the fault cannot be detected.

Justice Story stated the same rule; ${ }^{81}$ observing that many nations divide damages in inscrutable fault, he rejected Lord Stowell's dictum that division was limited to cases of mutual fault. ${ }^{82}$ The other principal nineteenth century American writers who touched the subject took the same position as Story and Kent. ${ }^{83}$

For the case of inevitable accident the rule was definitely settled by the Supreine Court in The Washington ${ }^{84}$ in accordance with the weight of

\footnotetext{
792 Dods. 83, 165 Eng. Rep. 1422 (1815).

803 Kent, CoMmantaries 184 (1828).

81 STORY, BAHINENT $\$ \$ 608,609$ (1832).

82 Id. $\$ 609$.

831 Conkinng, Admiralty 378 (2d ed. 1857); 1 Pansons, Merchantile Law 188 (1869).

8455 U.S. (14 How.) 532 (1852).
} 
opinion following Lord Stowell, to whose dictum the Court had earlier referred..$^{85}$ In The Washington the Court said: ${ }^{86}$

[I]n such cases [inevitable accident] the settled rule in admiralty in England is, that each vessel must bear its own loss, which rule has been heretofore recognized by this court, but has not been before directly applied.

But we think it more just and equitable, and more consistent with sound principles, that where the loss happens from a collision which is the result of inevitable accident, without the neghigence or fault of either party, each should bear his own.

The disposition of inevitable accident was by no means dispositive of inscrutable fault. The Civil Law had denied recovery for inevitable accident but appears to have granted it for inscrutable fault. Beginning with a dictum in 1847 some of the district courts have built a fairly substantial body of authority for the rule that division applies in cases of inscrutable fault. ${ }^{87}$ In an 1870 case the district court said: ${ }^{88}$

The American authorities, with scarcely an exception, affirm the rule of equal division in cases of inscrutable fault.

The court went on to show that it recognized very clearly the historically superior claims of inscrutable fault over mutual fault for the application of divided damages. ${ }^{89}$

In 1869, however, the Supreme Court said that ${ }^{90}$

Where there is a reasonable doubt as to which party is to blame, the loss must be sustained by the party on whom it has fallen.

There was nothing to indicate that this dictum was the result of any serious consideration on the part of the court, and the importance to be attached to it was argued thereafter in the lower courts, four of which, including the

85 The Louisville, 42 U.S. (1 How.) 89, 92 (1893).

8655 U.S. (14 How.) at 538.

87 The Kallisto, 14 Fed. Cas. 95, No. 7600 (E.D. Va. 1877); The Comet, 6 Fed. Cas. 195, No. 3050 (N.D.N.Y.1870), rev'd on other grounds, 6 Fed. Cas. 200, No. 3051 (C.C.N.D.N.Y. 1872); The Tracy J. Bronson, 24 Fed. Cas. 119, No. 14131 (N.D.N.Y.1869); The Bayard, 2 Fed. Cas. 1058, No. 1128 (W.D. Pa. 1869); The John Henry, 13 Fed. Cas. 684, No. 7350 (D.Me. 1860) ; The State of Maine, 13 Fed. Cas. 371, No. 7224 (N.D.N.Y. 1857); The Thomas Swann, 15 Fed. Cas. 1065, No. 8588 (D.O. 1854); see The David Dows, 16 Fed. 154 (N.D.N.Y. 1883); The J.W. Everman, 14 Fed. Cas. 64, No. 7591 (E.D. Va. 1874); The Nautilus, 17 Fed. Cas. 1251, No. 10058 (D. Me. 1854); The Scioto, 21 Fed. Cas. 774, No. 12508 (D. Me. 1847).

88 The Comet, 6 Fed. Cas. 195, 199, No. 3050 (N.D.N.Y. 1870), rev'd on other grounds, 6 Fed. Cas. 200, No. 3051 (C.C.N.D.N.Y. 1872).

80 "[S]o late as 1837 , a learned and able writer on mercantile law, in the London Law Magazine, in questioning the rule in cases of mutual fault, ventured to declare that no writer on maritime law applied the rule of equal partition to any case but that of inscrutable fault." Ibid.

00 The Grace Girdler, 74 U.S. (7 Wall.) 196, 203 (1868). 
Court of Appeals for the Second Circuit, have subsequently denied division in inscrutable fault. ${ }^{91}$

In The Worthington ${ }^{92}$ the district court, after reviewing the authorities for and against division, gave as its reason for denying division: ${ }^{03}$

There are certain fundamental principles of justice adopted by the English and American courts. ... Among these is that which prohibits a person being deprived of his hiberty or property without being proved guilty of some fault or dereliction.

In making this statement the court forgot for the moment that it was dealing with a world-wide civil law system and applied the inapplicable standards of another system. Instead of inquiring what the rule was in admiralty, it turned its back and sought the rule in the common law, where of course it was not to be found. Admiralty, with its in rem liabilities, frequently deprives persons of property without their being proved guilty of any personal fault or derehiction..$^{94}$

In its proper form inscrutable fault appears, not where there is a failure to show what happened, but where the occurrence is clear and the court is unable to decide what act or omission constituted fault. Since it is considered that, apart from inevitable accident-in which the force is always manifest-collisions do not occur without fault, it is fair, just, and historically sound to divide damages. In another class of cases, where the judge is actually unable to make up his mind what happened because of the contrariety of the evidence, the further question arises whether both sides have presented the case with all possible force. If the court believes that each side has put forward such proof as is available, then the result of division is agam a fair arrangement of risk-sharing.

The Brussels Collision Convention of $1910^{95}$ abolishes the rule of division in cases of inscrutable fault. While the United States, as the only major maritime nation which has not ratified the Convention, is free to divide

91 The Jumna, 149 Fed. 171 (2d Cir. 1906); The Banner, 225 Fed. 433 (S.D. Ala. 1915); The Worthington, 19 Fed. 836 (E.D. Mich. 1883); The Breeze, 4 Fed. Cas. 52, No. 1829 (C.C. S.D.N.Y. 1872).

92 Ibid.

93 Id. at 840.

04 Mr. Chief Justice Marshall, in The Little Charles, 26 Fed. Cas. 979, 982, No. 15612 (C.C. Va. 1818): "But this is not a proceeding against the owner; it is a proceeding against the vessel, for an offence committed by the vessel, which is not less an offence, and does not the less subject her to forfeiture, because it was committed witbout the authority, and against the will of the owner ...."; Mr. Justice Story, in The Brig Malek Adhel, 43 U.S. (2 How.) 210, 233 (1844): "It is not an uncommon course in the admiralty, acting under the law of nations, to treat the vessel in which or by which, or by the master or crew thereof, a wrong or offence has been done as the offender, without any regard whatsoever to the personal misconduct or responsibility of the owner thereof."; The Scow "6-S", 250 U.S. 269 (1919).

95 English translation, 6 BENED1CT, ADArratity 4 (6th ed. 1940). 
damages in cases of inscrutable fault, yet the uniform practice of the rest of the maritime world, under the Convention, evidences that the general maritime law is now otherwise, and the application of division in America may be termed a retrogressive tendency. At present it can only be said that while there is doubt about inscrutable fault, the rule of division is probably favored in some districts and is definitely rejected in others. The rule is sound historically and, the writer believes, on principle as well, but it cannot survive the Brussels Convention.

\section{B. Non-collision Cases}

\section{Personal injury}

At least by 1884 damages had been divided - and divided unequallyin cases of injury to a longshoreman and a seaman. In that year, in The Explorer,,$^{90}$ a longshoreman injured by joint fault of himself and the ship was allowed special, though not general, damages. In referring to the rule in collision cases, the district court said: ${ }^{87}$

I am disposed to hold that in cases of marine torts it is the rule of the courts of admiralty to exercise "a conscientious discretion and give or withhold damages upon enlarged principles of justice and equity."

The same court, in The Wanderer ${ }^{98}$ granted a similar recovery to a seaman jointly at fault with his ship, allowing him to recover to the extent of the cost of direct care, attention, medical services and expenses. Recovery was allowed, "not as a compensation for the injury, but as required by decency and humanity from a party without whose fault there would have been no injury."

In The Max Morris, ${ }^{100}$ in 1890, the Supreme Court was confronted with the question whether division should be applied to a personal injury case and by implication to non-collision cases generally. Judge Brown in the district court had allowed the libelant longshoreman his loss of wages on account of his injury, requiring him to bear all pain and suffering and consequential damages because of his concurring neghigence. ${ }^{101}$ In dividing damages in this way he followed The Explorer and The Wanderer and stated that "the practice in admiralty to apportion damages in cases of mutual fault is not strictly confined to collisions and prize causes."102 The circuit court affirmed, stating that the question presented was "whether the

8620 Fed. 135 (C.C.E.D. La. 1884).

87 Id. at 139.

8820 Fed. 140 (C.C.E.D. La. 1884).

89 Id. at 143.

100137 U.S. 1 (1890).

${ }^{101}$ The Max Morris, 24 Fed. 860 (S.D.N.Y. 1885).

102 Id. at 863. 
rule of admiralty for apportioning damages in collision is to be extended to ordinary actions for personal injuries sustained on board vessels by laborers, seamen, passengers, or others by reason of the concurring negligence of the party injured, and those for whose conduct the ship is responsible. ..."103 The court found The Explorer persuasive and the case of Atlee $v$. Packet $\mathrm{Co}^{104}$ determinative. It quoted the broad language of the Atlee case regarding division in cases of marine tort and then said: ${ }^{\mathbf{1 0 5}}$

Upon these views of the law, the collision rule for dividing damages can no longer be considered as applicable only to cases involving the rights and responsibilities of parties for colliding vessels. The principles enunciated apply to all cases of marine tort founded upon negligence, without regard to any peculiar considerations of maritime policy for regulating the conduct of ships towards each other, or to any exceptional rules of practice adopted by the admiralty courts because of the intrinsic difficulty in collision cases of locating the fault, or the cause of the disaster.

No decree was entered on this opinion of the circuit court and when the case came up a second time before the circuit court a decree was entered affirming the district court but certifying to the Supreme Court the question whether libelant was "entitled to a decree for divided damages." On this certificate the claimant appealed. The Supreme Court evidently understood "divided damages," without more, to mean equally divided damages, since at the outset, upon observing that damages below had not been equally divided, they interpreted the question certified as not being limited to "divided damages."106 As will be seen, however, their study of the question was concentrated on cases of equal division.

The Court first noted all the collision cases in which it had so far divided the damages. It then proceeded to review at length The Washington and The Gregory, ${ }^{107}$ The Alabama and the Gamecock, ${ }^{108}$ Atlee v. Packet Co., ${ }^{100}$ The Atlas, ${ }^{110}$ and The Juniata. ${ }^{111}$ It noted that in The Washington and The Gregory it had allowed an innocent passenger to take a decree for divided damages against both ships in collision and had thus "extended [the rule of equal division] to damages other than those sustained by either or both of the vessels in fault."112 The Court pointed to a similar result in The Alabama. The Atlee case was reviewed at length as one in which damages had

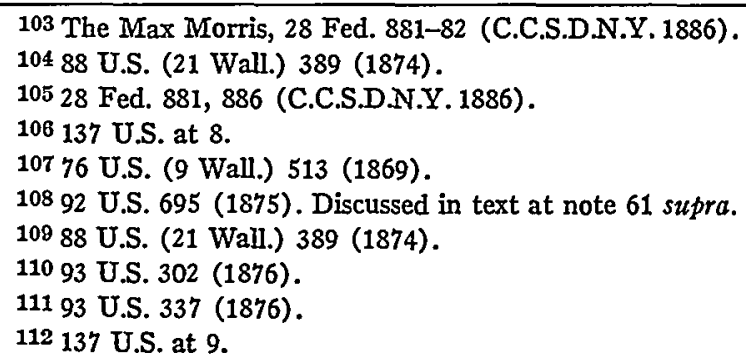


been divided where there was not actually a collision between two vessels and the Court quoted the language of the case indicating division to be the general rule of the admiralty. The Court observed that in The Atlas division had been applied to cargo damage in a collision case and that in The Juniata the tug owner who sued for damages to his tug and injuries to himself from a mutual fault collision had received a decree for half damages which quite evidently included his personal injuries, notwithstanding his own fault.

The Court then discussed several cases like that before it, among them The Explorer and The Wanderer, ${ }^{113}$ and noted support for those cases in its own earlier statements that: ${ }^{114}$

Even in cases of marine torts, independent of prize, courts of admiralty are in the habit of giving or withholding damages upon enlarged principles of justice and equity....

and further that: ${ }^{115}$

In the admiralty, the award of damages always rests in the sound discretion of the court, under all the circumstances.

The Court next reviewed a series of other non-collision cases, including cases of tug and tow, foul berth, and cargo damage in which the lower courts had divided damages: ${ }^{116}$

All these were cases in admiralty, and were not cases of collision between two vessels. They show an amehoration of the common law rule, and an extension of the admiralty rule in a direction which we think is manifestly just and proper.... We think this rule is applicable to all like cases of marine tort founded upon negligence and prosecuted in admiralty, as in harmony with the rule for the division of damages in cases of collision. The mere fact of the negligence of the libellant as partly occasioning the injuries to him, when they also occurred partly through the negligence of the officers of the vessel, does not debar him entirely from a recovery.

Finally, with respect to unequal division, the Court said: ${ }^{117}$

Whether, in a case bike this, the decree should be for exactly one half of the damages sustained, or might, in the discretion of the court, be for a greater or less proportion of such damages, is a question not presented for our determination upon this record, and we express no opinion upon it.

But if the Court expressed no opimion, its remarks were nevertheless re-

113 Discussed in text at notes 96-98 supra. Other cases discussed were The Truro, 31 Fed.

158 (E.D.N.Y. 1887), and The Eddystone, 33 Fed. 925 (E.D. Va. 1887).

${ }_{114}$ The Marianna Flora, 24 U.S. (11 Wheat.) I, 54 (1826).

115 The Palmyra, 25 U.S. (12 Wheat.) 1, 17 (1827).

116137 U.S. at 14-15.

117 Id. at 15 . 
garded as authority for continued unequal division by the lower courts, and it has since repeatedly approved that course. ${ }^{118}$

From its early application to a longshoreman's suit for negligence and a seaman's suit for breach of the warranty of seaworthiness, division according to fault has extended to the longshoreman's new remedy for unseaworthiness ${ }^{119}$ and, under the terms of the Jones Act, ${ }^{120}$ to the seaman's modern remedy for negligence. ${ }^{121}$ Nor is the passenger treated differently from the seaman and the longshoreman in non-collision cases; his damages, too, are divided $\mathrm{d}^{122}$ and may be apportioned according to degree of fault. ${ }^{123}$

\section{Tug and tow}

It has already been noted how damages are divided among the tug and tows of a flotilla in collision with a ship outside the flotilla. ${ }^{124}$ The law deals similarly with incidents within the flotilla involving the relationship between tug and tow, including faulty navigation of the tug imperiling the tow by grounding or capsizing, failure of the tug to move the tow properly or otherwise take precautions for her safety, and collision between tows through the fault of the tug.

In 1865 , in a case in which a tug was negligently navigated so that the towing hawser parted and the tow, for want of an anchor, went over Niagara Falls, damages were divided between the two vessels. ${ }^{125}$ Shortly thereafter, in a case involving a leaking, unseaworthy tow which was cast off by the tug to drift to her pier and instead drifted off and sank, the court divided the damages arising after the casting off, omitting the damages from leaking prior to that time. ${ }^{128} \mathrm{~A}$ number of cases have arisen from the sinking of ill-found or overloaded barges which were towed into rough and stormy waters when they should have been left in port until fairer weather. It has been uniformly held that damages should be divided in situations where the barge owner has been at fault in acquiescing in the trip, ${ }^{127}$ in failing to warn the tug that the barge was old and weak, ${ }^{128}$ or in the overloading or unsea-

118 See, e.g., Jacob v. New York City, 315 U.S. 752, 1942 A.M.C. 616; Socony-Vacuum Oil Co. v. Smith, 305 U.S. 424, 1939 A.M.C. 1; The Arizona, 298 U.S. 110, 1936 A.M.C. 627.

119 Pope \& Talbot v. Hawn, 346 U.S. 406, 1954 A.M.C. 1 (1953).

12041 STAT. 1007 (1920), 46 U.S.C. $\$ 688$ (1952).

121 Beadle v. Spencer, 298 U.S. 124, 1936 A.M.C. 635.

122 The Tourist, 265 Fed. 700 (D. Me. 1920).

123 The Lackawanna, 151 Fed. 499 (S.D.N.Y. 1907); see Byrd v. Napoleon Ave. Ferry Co., 125 F. Supp. 573, 1954 A.M.C. 2159 (E.D.La.), af'd, 227 F.2d 958, 1956 A.M.C. 515 (5th Cir.), cert. denied, 351 U.S. 925 (1956).

124 See text beginning at note 60 supra.

125 Cramer v. Allen, 6 Fed. Cas. 743, No. 3346 (C.C.N.D.N.Y. 1865).

${ }^{128}$ The J. L. Hasbrouck, 13 Fed. Cas. 639, No. 7324 (S.D.N.Y. 1871).

${ }^{127}$ The Bordentown, 16 Fed. 270 (S.D.N.X. 1883); The Steam Tug Willinm Cox, 3 Fed. 645 (S.D.N.Y. 1880), aff'd, 9 Fed. 672 (C.C.S.D.N.Y.1881); The Steam Tug William Murtaugh, 3 Fed. 404 (S.D.N.Y. 1880).

${ }^{128}$ The Syracuse, 18 Fed. 828 (S.D.N.Y. 1883); The Bordentown, sutpra note 127. 
worthiness of the barge. ${ }^{129}$ The same result has been reached where the tow was damaged by being run aground, ${ }^{130}$ improperly anchored or moored and breaking adrift, ${ }^{131}$ placed in a foul berth ${ }^{132}$ with the acquiescence or other fault of her bargee, or left neglected after suffering damage. ${ }^{133}$ Nor did it make any difference that the damage was suffered by a third vessel through the joint fault of tug and tow with respect to a mooring. ${ }^{134}$ Finally, damages were divided where two barges in a tow collided through the fault of one barge and the tug. ${ }^{135}$

Division of damages in this class of cases received the express approval of the Supreme Court in The Max Morris, ${ }^{136}$ where certain of them ${ }^{137}$ were cited as precedents for extending division to non-collision cases.

\section{Cargo damage}

Damages for injury to cargo through the joint fault of ship and shipper were divided at least a hundred years ago in Snow v. Carruth. ${ }^{138}$ The court found it difficult to determine how much damage was due to the fault of each party and so adopted the moiety rule of the collision cases. The court seemed to indicate that a different ratio might have been used if it were possible to assign the degrees of fault more precisely. ${ }^{139}$ The Supreme Court in The Max Morris expressly approved Snow v. Carruth and used it as one of the precedents upon which it based its endorsement of the extension of division of damages to personal injury cases. ${ }^{140}$ It was natural, therefore, that the Supreme Court would grant contribution in a subsequent grounding case in which the cargo damage was caused by joint fault of the ship and a canal company; $;^{141}$ the Court held the canal company liable to cargo owners and granted contribution from shipowners.

In The Nidarholm ${ }^{142}$ the charterer sued the shipowner for loss of cargo;

120 Glen Southern Shipping Corp. v. Norfolk Towing Corp., 135 F. Supp. 146, 1955 A.M.C. 1662 (E.D. Va.) ; The T. J. Hooper, 53 F.2d 107, 1931 A.M.C. 1764 (S.D.N.Y.), aff'd, 60 F.2d 737, 1932 A.M.C. 1169 (2d Cir.), cert. denied, 287 U.S. 662 ; Connolly v. Ross, 11 Fed. 342 (S.D.N.Y. 1882).

130 Russell, Poling \& Co. v. United States, 140 F. Supp. 890, 1956 A.M.C. 1106 (S.D.N.Y.).

131 The C. R. Stone, 68 Fed. 934 (S.D.N.Y. 1895).

132 The Nassau No. 10, 62 F.2d 356, 1933 A.M.C. 54 (2d Cir. 1932); The Bleakley No. 76, 54 F.2d 530, 1932 A.M.C. 17 (2d Cir. 1931).

133 Puget Sound Tug \& Barge Co. v. United States, 73 F. Supp. 1017, 1948 A.M.C. 151 (W.D. Wash. 1947); The Kard, 38 F.2d 844, 1930 A.M.C. 1255 (E.D. Pa.) ; The Young America, 26 Fed. 174 (S.D.N.Y. 1886), rev'd on other grounds, 31 Fed. 749 (C.C.S.D.N.Y.1887).

134 See The Daly No. 67, 45 F. Supp. 641, 1942 A.M.C. 1091 (E.D.N.Y.).

135 The Boston, 126 F. Supp. 641, 1955 A.M.C. 896 (E.D.N.Y.).

136137 U.S. 1 (1890).

137 Cases cited in notes 127 and 128 supra; Connolly v. Ross, 11 Fed. 342 (S.D.N.Y. 1882).

13822 Fed. Cas. 724, No. 13144 (D. Mass. 1856).

139 Id. at 726 .

140137 U.S. at 14.

141 White Oak Transp. Co. v. Boston, Cape Cod \& N.Y. Canal Co., 258 U.S. 341 (1922). 14234 F.2d 442, 1929 A.M.C. 1356 (1st Cir.). 
upon a showing of joint fault, breach of warranty of seaworthiness by the shipowner, and faulty stowage by the charterer, the court of appeals divided the damages. The charterer secured certiorari and the Supreme Court affirmed; ${ }^{143}$ the owner's fault, however, was not reviewed since the owner did not seek certiorari. ${ }^{144}$

There have been other applications of the moiety rule to cargo damage by the lower courts, ${ }^{145}$ and the Third Circuit has not let the Halcyon dictum deter it from dividing damages in a recent case where the cargo owner, as in The Nidarholm, sued the shipowner and the charterer. ${ }^{140}$

\section{Foul berth-wharfinger's and charterer's liability}

When barges break loose and drift away from a wharf through the joint fault of the wharfinger and the tug that moored them, the damages are divided. ${ }^{147}$ When the vessel grounds or breaks loose through the fault of wharfinger and vessel whose master or bargee has failed to take proper precautions, then wharfinger and vessel owner share the damages. ${ }^{148}$ The result is the same where the concurring fault is that of the consignee ${ }^{140}$ or the charterer $^{150}$ instead of the wharfinger or where the charterer and wharf-

143 The Nidarholm, 282 U.S. 681, 1931 A.M.C. 522.

$144 \mathrm{It}$ is hard to read the case as anything but an application by the Court of contribution to a non-collision cargo damage case, in view of the doctrine that the Supreme Court has often and emphatically pronounced, that an appeal by one party in admiralty is an appeal by all, bringing the case up for a trial de novo in which the Court will see substantial justice done for all. See Standard Oil Co. v. Southern Pacific Co., 268 U.S. 146 (1925); The John Twohy, 255 U.S. 77 (1921); Reid v. Fargo, 241 U.S. 544 (1916); The Hesper, 122 U.S. 256 (1887).

145 Cities Service Refining Corp. v. National Bulk Carriers, 146 F. Supp. 418, 1956 A.M.C. 1799 (S.D. Tex.) ; Kelley v. Pennsylvania R.R., 139 F. Supp. 658 (E.D.N.Y. 1956) ; The T. J. Hooper, 53 F.2d 107, 1931 A.M.C. 1764 (S.D.N.Y.), aff'd, 60 F.2d 737, 1932 A.M.C. 1169 (2d Cir.), cert. denied, 287 U.S. 662 (1932) ; The New York, 40 Fed. 900 (S.D.N.Y. 1889); sce W. R. Grace \& Co. v. Charleston Lighterage \& Transfer Co., 193 F.2d 539, 1952 A.M.C. 689 (4th Cir.) (district court reduced damages for cargo loss from sinking of unseaworthy barge by $10 \%$ for lack of diligence of cargo owners in salving cargo; court of appeals reversed as not supported by facts); The Steam Tug William Murtaugh, 17 Fed. 259 (S.D.N.Y. 1883).

146 Crain Bros. v. Wieman and Ward Co., 223 F.2d 256, 1955 A.M.C. 1206 (3d Cir.).

147 The Allen B. Wood, 121 F. Supp. 704, 1954 A.M.C. 1389 (E.D.La.), aff'd, 219 F.2d 237, 1955 A.M.C. 552 (5th Cir.) ; The Conway Bros., 1929 A.M.C. 822 (E.D.N.Y.).

148 The Southport, 190 F.2d 699, 1951 A.M.C. 1511 (4th Cir.); The Scow No. 73-H, 130 F.2d 96, 1942 A.M.C. 1159 (2d Cir.); The Ranger, 98 F.2d 770, 1938 A.M.C. 1204 (2d Cir.); The President Madison, 91 F.2d 835, 1937 A.M.C. 1375 (9th Cir.) ; Union Ice Co. v. Crowell, 55 Fed. 87 (1st Cir. 1893); Kelley v. Pennsylvania R.R., 139 F. Supp. 658 (E.D.N.Y. 1956); Sullivan v. Lake Superior Elevator Co., 56 Fed. 735 (D. Minn. 1893) (trestle on wharf blew down on ship); Christian v. Van Tassel, 12 Fed. 884 (S.D.N.Y. 1882); see The Halo, 79 F.2d 521, 1935 A.M.C. 1513 (2d Cir.) (foul herth cases in which damages will he divided are set forth).

140 James H. Rhodes \& Co. v. U.S. Lighterage Corp., 98 F.2d 770, 1938 A.M.C. 1204 (2d Cir.) ; The Lumber Jack, 1933 A.M.C. 743 (S.D.N.Y.); O'Boyle v. New York Steam Co., 254 Fed. 640 (E.D.N.Y. 1918).

150 The Westfield, 1925 A.M.C. 965 (E.D.N.Y.) ; Constantine \& Pickering S.S. Co. v. West India S.S. Co., 199 Fed. 964 (S.D.N.Y.1912). 
inger, but not the vessel, are at fault. ${ }^{151}$ Not only are damages divided for concurring fault of the vessel in foul berth cases but also for failure of the vessel to mitigate the damages by leaving the berth as soon as possible upon discovering that damage is being done. ${ }^{152}$ Again in this class of cases, at least so far as wharfinger's liability for foul berth is concerned, the Supreme Court has endorsed division of damages by approving Christian v. Van Tassel $^{153}$ in The Max Morris.

\section{Crowding and swell damage}

In cases where one vessel crowds another, that is, maneuvers so as to embarrass the navigation of the other, with the result that damage is caused by the crowded vessel's grounding or colliding with a third vessel or fixed object, damages are divided if the crowded vessel is also at fault, notwithstanding that no collision occurs between crowding and crowded vessel. ${ }^{154}$ Such cases are treated in all respects like collision cases.

In the similar case of swell damage mutual fault may also occur. Damages have been divided between a steamer whose swells caused barges in a tow to strike together and the tug which failed to lengthen the tow line in the face of danger. ${ }^{155}$ Damages have also been divided where wash combined with lack of care of a berth or a barge to cause cargo damage ${ }^{156}$ and similarly where a tug allowed her tow to get too near the bank where it was grounded by the wash of a vessel passing at excessive speed. ${ }^{157}$

\section{Age and unseaworthiness}

In one class of cases division is based not upon anything that would ordinarily be called the fault of the contributing party, but upon what might be termed an assumption of risk. These are the cases in which $A$ is at fault and $B$ is free from fault, yet the damage to $B$ 's vessel is divided because she was so old or unseaworthy that she could not stand the buffeting to be expected in ordinary commerce. This application of division, which has its roots solidly in the ancient codes, is again the product of Judge Addison Brown. The cases of age or unseaworthiness are to be distinguished from the cases already cited, ${ }^{158}$ in which weak tows divided their damage equally

151 The Mascot, 28 F. Supp. 770, 1939 A.M.C. 1263 (D.N.J.).

152 The Lumber Jack, 1933 A.M.C. 743 (S.D.N.Y.) ; Scouten v. Abendroth Bros., 1928 A.M.C. 1396 (S.D.N.Y.) ; The Mary E. Waldie, 22 F.2d 328, 1928 A.M.C. 276 (S.D.N.Y. 1927). 15312 Fed. 884 (S.D.N.Y. 1882).

154 The Empire Garrick, 93 F. Supp. 718, 1950 A.M.C. 1552 (S.D.N.Y.); The M/V Sandmaster, 26 F. Supp. 64, 1938 A.M.C. 1471 (S.D.N.Y.), modified, 105 F.2d 1009, 1939 A.M.C. 1341 (2d Cir.).

155 The Hendrick Hudson, 43 F.2d 566, 1930 A.M.C. 1421 (E.D.N.Y.).

156 Cities Service Refining Corp. v. National Bulk Carriers, 146 F. Supp. 418, 1956 A.M.C.

1799 (S.D.Tex.) ; The New York, 40 Fed. 900 (S.D.N.Y. 1889).

157 The Detroiter, 82 F.2d 234, 1936 A.M.C. 382 (2d Cir.).

158 See notes $31-34$ sitpra. 
with their tugs. In the former there is no participation or acquiescence by the owner of the weak vesel in the actual fault leading to the damage.

In The Bordentoren ${ }^{159}$ an old and unfit barge had been put in the lead position of a tow with the acquiescence of her owner and had sunk in a gale. Judge Brown referred to article 14 of the Laws of Oleron and article 26 of the Laws of Wisby, on division of damages where one vessel is old and weak, and said : "Nor can it be suffered that old barges be run until they sink, and the whole loss be then charged upon the tug." 180 A year later in The $R e b a^{161}$ he reached a similar result in a case where the damaged canal boat had in no sense been an active participant in the cause of her harm but had been moored in a slip when she was struck by an entering boat. The damaged boat shared in her own damages because she was found to be old and to have decayed and rotten timbers. The judge said that division could be avoided if the owner gave notice of her weakness upon the approach of other vessels so as to charge them with special care to stay clear. This case, together with another in which the bargee of an ill-found barge asked the tug to seek shelter and the tug failed to do so with the result that the barge sank, ${ }^{162}$ were among those cited with approval and followed by the Supreme Court in The Max Morris.

In The N. B. Starbuck ${ }^{163}$ a moored schooner was struck by a tug through the fault of the latter. The schooner's timbers were found to be rotten. Judge Brown there said: ${ }^{164}$

[T] here is sufficient evidence of the rottenness of the wood exposed in the side of the libelant's schooner, when she was repaired, to convince me that the schooner was not in a condition of fair or ordinary strength, but weak, and unfit for the usual contacts of vessels about the slips.... It is impossible to tell what injury would have been inflicted on a sound schooner by a blow such as this, while $I$ have no doubt that it would have been much less than happened to this schooner. There is no other way, therefore, than to divide the damages, as was done in the cases cited; since both are to be treated as in fault, contributing to the damage that actually occurred. To allow old boats, that give no notice of their weakness, a right to be fully repaired, would encourage them to run in the way of others.

The same result has been consistently reached in other cases $^{105}$ and may undoubtedly be regarded as representing the present state of the law.

15016 Fed. 270 (S.D.N.Y. 1883).

$160 \mathrm{Id}$. at 274.

16122 Fed. 546 (S.D.N.Y. 1884).

162 Philadelphia \& R.R. Co. v. New England Transp. Co., 24 Fed. 505 (S.D.N.Y. 1885).

16329 Fed. 797 (S.D.N.Y. 1887).

164 Id. at 798.

165 The City of Augusta, 30 Fed. 844 (S.D.N.Y. 1887) ; see Kelley v. Pennsylvania R.R., 139 F. Supp. 658 (E.D.N.Y. 1956); The Ellen S. Bouchard, 128 F. Supp. 16, 22, 1955 A.M.C. 572, 578 (N.D.N.Y.), aff'd, 229 F.2d 436, 1956 A.M.C. 297 (2d Cir.) ("The half damage principle in the law applied to old and infirm boats is applied to situations where the boats do not have the fair and ordinary strength to resist slight or ordinary contact."); The Gilson, 35 Fed. 333 (N.D.N.Y. 1888). 


\section{Grounding}

The plainest proof of the error of the Supreme Court's dictum in $\mathrm{Hal}$ cyon to the effect that there is no contribution in non-collision cases is found in White Oak Transp. Co. v. Boston, Cape Cod \& N.Y. Canal Co., ${ }^{186}$ where a vessel grounded in the Cape Cod Canal as the result of negligent navigation combined with the canal company's misrepresentation that the depth of water was adequate for the ship. The Supreme Court held that ship and canal were to divide their respective damages ${ }^{167}$ and that the canal company, which had been sued by cargo owners, was entitled to contribution from the shipowners for cargo damage as well. In a recent grounding case ${ }^{168}$ a district court held that the White Oak case states the rule in grounding cases and is not affected by Halcyon. Division in groundings continues ${ }^{169}$ and may certainly still be regarded as the rule.

\section{Stevedore damage to vessels}

Damage caused jointly by a stevedore and the vessel being loaded or discharged is divided. Examples of such division occur where the stevedore, with the bargee's acquiescence, so loads a barge that she capsizes, ${ }^{170}$ hangs up on an obstacle such as a ship's propeller, ${ }^{171}$ or slifts so that she is damaged. ${ }^{172}$ An additional example occurs where the stevedore's negligence concurs with that of a vessel in lowering drafts of cargo into a lighter alongside with such violence that the lighter is damaged. ${ }^{173}$ Damages are divided in these cases notwithstanding that in some of them the relations of the parties appear to be governed entirely by contract rather than tort liability.

\section{Repair, supply, and service contracts}

In some of the newest applications of divided damages, the delictual element is completely lacking and division is granted between contracting parties whose relations are unclouded by any such notions of tort as remain to confuse the issue in cargo and towage cases. In a 1930 case the charterer of a lighter was allowed to recover contribution from the lighter owner for

106258 U.S. 341 (1922); see also text at note 141 supra.

167 Cf. Somerset Seafood Co. v. Umited States, 193 F.2d 631, 1952 A.M.C. 697 (4th Cir. 1951).

169 Russell, Poling \& Co. v. Umited States, 140 F. Supp. 890, 1956 A.M.C. 1106 (S.D.N.Y.). 169 The Tug Bo-Buck, 1956 A.M.C. 1540 (S.D.Tex.).

170 Smith Scow Corp. v. Seaboard Great Lakes Corp., 146 F.2d 535, 1945 A.M.C. 151 (2d Cir.) ; see W. E. Hedger Transportation Co. v. United Fruit Co., 198 F.2d 376, 1952 A.M.C. 1469 (2d Cir.), cert. denied, 344 U.S. 896 (1952).

171 The Teno, 47 F.2d 197, 1931 A.M.C. 309 (2d Cir.).

172 The Robin Tuxford, 92 F. Supp. 902, 1950 A.M.C. 1081 (E.D.N.Y.); Sargent Barge Line v. New York Silk Dyeing Co., 3 F. Supp. 566, 1933 A.M.C. 742 (E.D.N.Y.), aff'd, 68 F.2d 1014, 1934 A.M.C. 159 (2d Cir.); see The William J. Tracy, 105 F. Supp. 910, 1952 A.M.C. 2017 (D.N.J.).

${ }^{173}$ Smith v. Nicholson Transit Co., 39 F. Supp. 795, 1941 A.M.C. 909 (W.D.N.Y.). 
damages the charterer had paid to a longshoreman injured as a result of a defective appliance on the lighter. The court put the recovery on the basis of breach of the warranty of seaworthiness contained in the charter. ${ }^{174}$ It has been held that repairmen divide damages with the shipowner where the repairmen failed to perform their contract work properly and the owner's concurrent negligence thereafter contributed to the damage. ${ }^{175}$ And where a tug's propeller was damaged by striking an underground cable, through the joint fault of the city which owned the cable and the contractor who laid the cable, the damages were divided between the contractor and the city. ${ }^{170}$

In a recent case of considerable significance, the Court of Appeals for the Fifth Circuit held that if the district court were unable to determine whiat part of fire damage to a tug had been caused by the yard which had started the fire and what part by failure of the tug to mitigate damage, then the maritime rule of equal division should be applied; the court clearly indicated that it regarded the yard's fault to be a breach of contract. ${ }^{177}$ The court's reliance at this point upon the recent decision of the Supreme Court in Ryan Stevedoring Co. v. Pan Atlantic S.S. Co ${ }^{178}$ brings into sharp focus the main problem of applying division to breaches of contract. In the $R y a n$ case itself the entire burden of a longshoreman's injury was cast over upon his employer, the impleaded stevedoring company, on the basis of breach of the stevedoring contract. It appears that negligence as well as unseaworthiness was found on the part of the ship and yet there was no division, full recovery being granted evidently upon the basis that the ship liad contracted to have a certain standard of care fully maintained by the contractor and was entitled to damages when this was not done.

\section{Death}

Admiralty, like the common law, afforded no right to recover for wrongful death. ${ }^{179}$ After wrongful death statutes had been adopted by various states the question arose whether admiralty would enforce the rights so created where death had resulted from a maritime tort within the body of the state. In 1886 the Supreme Court, while denying recovery on the ground that the libelant was time-barred under the state statute, indicated that recovery would ordinarily be available, subject, however, to all the limitations placed upon it by the state. ${ }^{180}$ In 1921 the Supreme Court again denied re-

${ }^{174}$ New York \& P.R.S.S. Co. v. Lee's Lighters, 48 F.2d 372, 1931 A.M.C. 140 (E.D.N.Y. 1930).

175 The Ipswich, 1935 A.M.C. 203 (S.D.N.Y.); The E.G.B. Riley, 1932 A.M.C. 974 (E.D.N.Y.).

170 The Wonder, 79 F.2d 312, 1935 A.M.C. 1310 (2d Cir.).

177 Southport Transit Co. v. Avondale Marine Ways, 234 F.2d 947, 1956 A.M.C. 1498

(5th Cir.).

178350 U.S. 124, 1956 A.M.C. 9, 44 CALIF. L. REv. 800 (1956).

179 See The Harrisburg, 119 U.S. 199 (1886).

180 Ibid. 
covery under a state statute on the strength of the state statute of limitations, ${ }^{181}$ emphasizing the fact that the right and the time limitation both had been created by the same statute.

While the Supreme Court has not considered the effect of joint fault in a death case arising in admiralty under a state act, the lower courts, taking their cue from statements that all the limitations imposed by the states apply, have for many years consistently held that where contributory negligence would be a complete defense under state law it will have the same effect $\mathrm{m}$ admiralty, evidently regardless of whether the bar is set forth in the state death act itself. ${ }^{182}$

In 1920 Congress passed the United States Death Act, ${ }^{183}$ more contmonly known as the Death on the Higl Seas Act, to provide a remedy for wrongful death on navigable waters outside the limits of any state and hence outside the operation of state statutes. The act provides for the application of division on the comparative fault principle in cases of joint fault and so is in accord with the general maritime law as to personal injuries and with the statutory provisions applicable to seamen under the Jones Act. ${ }^{184}$

In 1953 the Supreme Court inade some remarks which have reopened the subject of division under state death acts. In Pope \& Talbot v. Hawn, ${ }^{185}$ a case dealing with maritime personal injuries short of death in which it was contended that a state statute on contributory negligence slould apply in a diversity suit, the Court said: ${ }^{186}$

The harsh rule of the common law under which contributory negligence wholly barred an mjured person from recovery is completely incompatible with modern admiralty policy and practice. Exercising its traditional discretion, admiralty has developed and now follows its own fairer and more flexible rule which allows such consideration of contributory negligence in mitigation of damages as justice requires. Petitioner presents no persuasive arguments that admiralty should now adopt a discredited doctrine which automatically destroys all claims of injured persons who have contributed to their injuries in any degree, however slight.

... [T] he basis of Hawn's action is a maritime tort, a type of action which the Constitution has placed under national power to control in "its

181 Western Fuel Co. v. Garcia, 257 U.S. 233 (1921).

182 E.g., Monongahela River Consol. Coal \& Coke Co. v. Schinnerer, 196 Fed. 375 (6th Cir. 1912), cert. denied, 226 U.S. 608, 612 (1912); Morrissette v. Gulf Refining Co., 127 F. Supp. 469, 1955 A.M.C. 197 (E.D. La. 1954), affd, 230 F.2d 346, 1956 A.M.C. 527 (5th Cir.), cert. denied, 352 U.S. 832 (1956) ; Byrd v. Napoleon Ave. Ferry Co., 125 F. Supp. 573, 1954 A.M.C. 2159 (E.D. La.), affd, 227 F.2d 958, 1956 A.M.C. 515 (5th Cir. 1955), cert. denied, 351 U.S. 925 (1956).

18341 STAT. 537 (1920), 46 U.S.C. $\$ \S 761-68$ (1952).

184 See text at note 120 supra.

185346 U.S. 406, 1954 A.M.C. 1 (1953).

186 Id. at 408-09, 1954 A.M.C. at 6-7 (Emphasis added). 
substantive as well as its procedural features. ..." ... Even if Hawn were seeking to enforce a State created remedy for this right, federal maritime law would be controlling.

This vigorous condemnation of the common law rule together with the statement italicized above has been taken by some to mean that the common law rule will no longer apply even to death actions under state statutes. Of the lower courts that have considered the matter, the Court of Appeals for the First Circuit appears to have adopted this view ${ }^{187}$ and the Courts of Appeals for the Fifth and Sixth Circuits have plainly rejected it. ${ }^{188}$ Significantly, in one case the district court pointed out that the Supreme Court had referred to a "state-created remedy" and not a state-created right and thus had only said what was already well-known and accepted-that where a substantive right is created by the maritime law it must be given effect regardless of the forum or type of action. ${ }^{189}$ Nevertheless the strong language of the Hawn case remains; it may be supposed that when a state death act case reaches the Supreme Court, the Court will find itself only a step away from division of damages and eager to take the step. ${ }^{100}$

\section{Successive damage and avoidable consequences}

In The Young America ${ }^{101}$ a barge struck a rock through no fault of her tug and the tug left her aground and unattended while she went for assistance. When aid arrived the barge was found in possession of wreckers and the ensuing delay resulted in almost total loss. Judge Brown divided the total damage to the barge equally between the owner, who was not at fault, and the tug which was at fault in leaving the barge unattended, upon the ground that the original damage from the rock could not be separated from the aggravation due to delay.

This application of division to a situation where there is really no mutual fault but only an inability to determine the proportion of damage caused by the party at fault has recently received a full and considered exposition in the Fifth Circuit in a case where the shipyard was held at fault for a fire aboard a tug under repairs and the tug owner was held to

187 See O'Leary v. United States Lines, 215 F.2d 708, 1954 A.M.C. 1772 (1st Cir.), cerl. denied, 348 U.S. 939 (1955).

188 Morrissette v. Gulf Refining Co., 127 F. Supp. 469, 1955 A.M.C. 197 (E.D. La. 1954), aff'd, 231 F.2d 346, 1956 A.M.C. 527 (5th Cir.), cerl. denied, 352 U.S. 832 (1956); Byrd v. Napoleon Ave. Ferry Co., 125 F. Supp. 573, 1954 A.M.C. 2159 (E.D.La.), af'd, 227 F.2d 958, 1956 A.M.C. 515 (5th Cir. 1955), cert. denied, 351 U.S. 925 (1956); Niepert v. Cleveland Electric Illuminating Co., 241 F.2d 916, 1957 A.M.C. 1258 (6th Cir.).

189 Byrd v. Napoleon Ave. Ferry Co., 125 F. Supp. 573, 577, 1954 A.M.C. 2159, 2164 (E.D. La.).

190 Seemingly there would be great difficulty if the state death act itself established contributory negligence as a bar, but it is doubted whether any state acts do so ; certainly such acts are few.

10126 Fed. 174 (S.D.N.Y. 1886), rev'd on other grounds, 31 Fed. 749 (C.C.S.D.N.Y.1887). 
have failed to mitigate damages. ${ }^{192}$ The court remanded to the lower court with directions to determine the damage caused by each party, and if unable, to divide the damage equally ${ }^{103}$

Nor will inability satisfactorily to differentiate between the consequences of the tortfeasor's conduct and the innocent injured party's inaction be measured or its significance determined by common law notions which might deny recovery altogether. . . . If the tug owner's action in twice attempting to extinguish the fire by these simple means and twice believing that the job was done, was imprudent, it varies none in quality or character from the similar and post event breaches by the shipyard. In such a situation to visit all of the consequences on the innocent property owner whose only 'duty' to act came into being because of the contractor's initial and subsequent wrongs merely because he cannot adequately separate them would be harsh indeed and completely out of keeping with the fairer and more enlightened admiralty rule of divided damages.

Thus it is argued, with considerable justice, that in cases of successive damage from different causes the rule of division may be used, in the absence of mutual fault, as a rough rule of equity to avoid the harshness with which the common law would deny recovery altogether.

\section{Miscellaneous cases}

The difficulty of classifying every case of mutual fault under some one of the common classes of maritime cases has not prevented the application of divided damages. A yacht owner, seeing a water boat poorly moored alongside his yacht, was held to have a duty to take steps to protect his own yacht so that when the water boat later parted her moorings and drifted aft, damaging the yacht, damages were divided. ${ }^{194}$

The owner of a barge which had been squeezed by another at her berth at low tide sued the charterer of his barge and the owner of the other. Damages were divided between the charterer and the second barge for the failure of the charterer to move farther out of the slip and clear of the danger created by the second barge, the court saying: ${ }^{195}$

The fact that this duty is forced upon the second vessel by the initial wrong of the first, does not excuse the second, any more than at common law under the doctrine of the "last clear chance", the second comer is excused.

102 Southport Transit Co. v. Avondale Marine Ways, 234 F.2d 947, 1956 A.M.C. 1498 (5th Cir.).

193 Id. at 954-55, 1956 A.M.C. at 1507-08.

194 The H. B. Moore, Jr., 127 Fed. 319 (2d Cir. 1903).

105 The James E. Elliott, 205 F.2d 257, 259, 1953 A.M.C. 1254, 1257 (2d Cir.). In another ruling, based on last clear chance, damages were divided where a launch alongside was struck and sunk by the propellor while a ship was getting underway. The Norcuba, 142 F. Supp. 377, 1957 A.M.C. 82 (S.D.N.Y. 1956), rev'd on other grounds, 243 F.2d 890, 1957 A.M.C. 1219 (2d Cir.). 
Finally, and to show perhaps that the limit is set only by the tortious propensity of man, the damages were equally divided where guards on a vessel fired into an unruly group of strikers on the pier during a strike characterized by violence and rioting. ${ }^{198}$

\section{C.Theoretical Vieres}

Contribution in admiralty is not mere subrogation and, in consequence, the party sued for contribution does not enjoy the advantage of personal defenses he may have had as to the injured party nor even the protection of a statute of himitations which would bar suit if brought by the original libelant. ${ }^{197}$ The courts have pointed out that, unlike contribution at law, which is adjustment between tortfeasors founded upon principles of equity and not of tort hability, contribution in admiralty is a substantive right arising directly from the tort. ${ }^{198}$

Despite the inclination of courts to discuss contribution as though it were only a tort matter, it may be more desirable to say that it arises from a breach of duty. The somewhat artificial dichotomy which exists in the common law between torts and contracts has not traditionally been observed in admiralty. The admiralty courts are civil law courts and the civil law in general has never experienced the agonies of the common law writ system and has never observed a sharp distinction between contractual and delictual rights. Accordingly, in numerous instances already cited, contribution or division has been allowed in cases of breach of contract. ${ }^{100}$ While contribution for breach of contract raises certain problems, ${ }^{200}$ the flexibility of admiralty on this point, as on others where it contrasts with common law rigidity, should be recognized and perpetuated as a means of doing substantial justice.

Althougl contribution in admiralty arises out of the joint acts of independent parties and must not be confused with primary and secondary liability for the same act, ${ }^{201}$ it is said that when a decree is entered dividing A's damages between $B$ and $C$, the latter stand in the position of sureties

198 The Wichita Falls, I5 F. Supp. 612, 1936 A.M.C. I364 (S.D. Tex.).

107 The Tampico, 45 F. Supp. 174, 1942 A.M.C. 955 (W.D.N.Y.); The Conemaugh, 135 Fed. 240 (N.D. III. 1904).

198 See, e.g., Stradley v. Capital Transit Co., 87 F. Supp. 94 (D.D.C. 1949), aff'd, 183 F.2d 825 (D.C.Cir. 1950), rev'd on other grounds, 340 U.S. 543 (1951); Drummond v. United States, 78 F. Supp. 750 (E.D. Va. 1948); The Tampico, 45 F. Supp. 174, 1942 A.M.C. 955 (W.D.N.Y.).

190 See, e.g., text at notes 65 and 66 supra.

200 See text at note 177 supra. (1920).

201 The Willem Van Driel, Sr., 261 Fed. 269 (4th Cir. 1919), cert. denied, 252 U.S. 584 
towards each other. ${ }^{202}$ This arises from the requirement of the decree that one-half only be collected from each of $B$ and $C$ except in the event one does not pay, in which case the other is held for the deficiency. The result of this doctrine, as illustrated in the cases just cited, is that where B has purchased claims of $\mathrm{A}$ for cash at less than full value or for goods or services at a rate including an element of profit, he may only collect from $\mathrm{C}$ as contribution one-half the amount the claims cost him and not one-half the full value of the claims to A. ${ }^{203}$ In short, equitable considerations are applied at every point and no profit may be taken from a co-contributor.

\section{Procedural Considerations}

\section{Suits in admiralty}

In general, admiralty does not permit the party's substantive rights or obligations to be varied by the choice of procedures which may be open to him or his adversary. As Justice Holmes said in The Eugene F. Moran, ${ }^{204}$ " $[T]$ he quantum of liability ought not to be affected by the position of the party concerned as co-defendant or plaintiff." But in admiralty cases, as elsewhere, the rules must be followed, rehef must be prayed for to be received, and the party who at some stage of the case discovers that he is entitled to contribution from another party in the case cannot have it if he has failed to file a libel, cross-libel or impleading petition praying therefor. ${ }^{205}$ The failure to plead, however, will not bar a later separate action in admiralty to recover contribution, ${ }^{206}$ and the fact that the original judgment was rendered in a case at law, rather than in admiralty, will not affect the important right to this procedure. As the Supreme Court said in The Ira $M$. Hedges: :07 $^{20}$

The right to contribution belongs to the substantive law of the admiralty. ... It is not a mere incident of a forn of procedure. Therefore the fact, over which the libelant had no control, that the injured party saw fit to sue at common law, cannot take that right away. The passing of the claim against the libellant into the form of a judgment before the claim was satisfied has no bearing upon the question whether the right to contribution remains. It does not matter to this question, even if it be true, as thought by the court below, that the libellant might have required the owner of the Ira M. Hedges to be inade a party.

202 The Perth Amboy No. 2, 110 F.2d 644, 1940 A.M.C. 621 (2d Cir.); The Gulf Stream, 64 Fed. 809 (2d Cir. 1894); see The Mariska, 107 Fed. 989 (7th Cir. 1901); The Hudson, 15 Fed. 162 (S.D.N.Y. 1883).

203 The Perth Amboy No. 2, supra note 202; The Gulf Stream, supra note 202.

204212 U.S. 466, 476 (1909).

205 The Conemaugb, 189 U.S. 363 (1903).

206 Erie R.R. v. Erie \& Western Trans. Co., 204 U.S. 220 (1907).

207218 U.S. 264, 270-71 (1910). 
If only one party alleges and proves damages, the court, in dividing damages, need not inquire as to damages of the other party but should simply enter a decree for one-half the damages ${ }^{208}$-or any other appropriate percentage of damages in personal injury cases. But where two parties at fault prove damages there is still only a single decree, in favor of the party which suffered most against him who suffered least, for one-half the difference between the amounts of their respective losses. ${ }^{200}$ In cases where one party proves damages resulting from the fault of two others, but has sued only one of them, he is entitled to a decree for his damages in full, leaving the respondent to seek contribution by a separate suit ${ }^{210}$ or to recoup out of damages which he may be required to pay his joint obligor arising from the same collision or transaction. ${ }^{211}$ Where, however, the injured party has sued both wrongdoers, the only proper decree is against each for his own share with a right against each for the remainder in the event of inability to collect it from the other party. ${ }^{212}$ The rules will of course be applied mutatis mutandis where three or more parties may be found at fault.

In the great flexibility of admiralty procedure a reasonable exception to the rule of a single decree was allowed by Judge Brown in a case where the evidence on the trial clearly showed liability of one respondent but did not resolve the question as to the other. ${ }^{213}$ The court passed a decree for full damages against the one, continuing the case for further trial as between the respondents. Flexibility does not, however, permit a party to profit by mnltiplicity of suits. Thus where three parties-A, B and Cwere at fault and $A$ sued $B$ and $B$ then sued $C$ separately; $B$ was not allowed to recover under the two mutual fault decrees more than the two-thirds damages he could have recovered in a single proceeding by all parties. ${ }^{214}$

\section{Limitation of liability}

An important question arose when limitation of liability came to be applied in connection with division of damages. In The North Star ${ }^{215}$ it was contended that if one vessel were a total loss and ler limitation value nothing, and if the Limitation Act ${ }^{218}$ were applied before striking the

208 The Sapphire, 85 U.S. (18 Wall.) 51 (1873).

209 The Manitoba, 122 U.S. 97 (1887).

210 The Juniata, 93 U.S. 337 (1876).

211 The Albert Dumois, 177 U.S. 240 (1900).

212 See The Alabama and the Gamecock, 92 U.S. 695 (1875) ; The Virginia Ehrman, 97 U.S. 309 (1877).

213 The Alert, 44 Fed. 685 (S.D.N.Y. 1890), aff'd, 61 Fed. 113 (2d Cir. 1894).

214 The Peter Moran, 94 F. Supp. 520, 1951 A.M.C. 58 (S.D.N.Y. 1950).

215106 U.S. 17 (1882).

216 REv. STAT. $\$ 4283$ (1875), 46 U.S.C. $\S 183$ (1952). This act, with soune qualification in personal injury cases, limits the vessel owner's hability to the value of the vessel in cases where he is not in privity with the cause of dainage. 
balance in a mutual fault decree, then, since her hability would be nothing, she would recover one-half of her damages undiminished by one-half the damage of the other vessel. The Supreme Court rejected this contention, holding that only a single liability arises in mutual fault cases-the liability of one party to the other for the balance as expressed in the proper form of decree already described above. ${ }^{217}$ Consequently, the balance is to be struck and the himitation of liability applied only to that balance and on behalf of the party otherwise required to pay it.

A claim for contribution, like any other claim, may be presented in a limitation of liability proceeding. It is not necessary that the petitioner in the proceeding have been a party to the earlier suit in which the claimant's liability was enforced. ${ }^{218}$ The right of the claimant is not foreclosed by the fact that the persons to whom he is liable have not yet made their claim against him since he need only present in the limitation proceeding a contingent claim for contribution of amounts for which he may be held liable in the future. ${ }^{219}$

The procedure of limitation of liability may produce one substantial difference in respect of the right of an innocent party to a full recovery. We have seen that the innocent party who sues only one of two others at fault may recover his entire damages; but in The $V o c o,{ }^{220}$ a limitation case, that was not the result. In that case three vessels were at fault in a collision with still a fourth vessel and two of the three filed petitions to limit liability. The fourth and innocent vessel made her claims and the court allowed her only two-thirds of her damages since she had not claimed against the third vessel at fault, which was also present in the consolidated action. The reason for not allowing the innocent vessel to recover her full damages from the vessels she claimed against, although not made clear by the court, would appear to be that such a decree would allow the claimant, by claiming all his damages in the himitation action, to deplete the fund available to other parties who might have no other source to look to for recovery. If this is the reason, the rule has much to recommend it; it seems equitable to require a party who may claim both in a limitation proceeding and outside it to prosecute his outside claim and so minimize the extent to which his claim will deplete the available limitation fund.

\section{Cases at law}

At one time the substantive character of contribution in admiralty was lost from sight and the misconception that contribution was a matter of

217 Text at note 212 supra.

218 The Scow No. 34, 182 Fed. 179 (D. Mass. 1909).

219 Ibid.

22093 F. Supp. 718, 1950 A.M.C. 1552 (S.D.N.Y.). 
the law of the forum reached the Supreme Court, which said, in Belden v. Chase, ${ }^{221}$ that recovery in a maritime action in a state court would be barred by contributory negligence under the state rule. Belden v. Chase has now been overruled, albeit sub silentio, and it is clear that the rules of the maritime law, including the maritime rule of contribution and division, must be applied as substantive law in state court actions. ${ }^{222}$

\section{III}

THE MODERN LAW IN OTHER JURISDICTIONS

Whatever divergences previously existed among the practices of nations, the International Convention for the Unification of Certain Rules of Law in Regard to Collisions, ${ }^{223}$ signed by most of the maritime nations of the world in Brussels in 1910, has produced a uniform rule for most of the world with regard to contribution in collision cases and other cases of damage caused by one vessel to another or to persons or property aboard her.

The Convention has been ratified or adhered to by most of the maritime nations, including every major one except the United States. ${ }^{224}$ As a result, it may be said that practically everywhere the rules are: (1) that contribution is available in collision cases and other cases of damage by one

221150 U.S. 674 (1893).

222 See, e.g., Pope \& Talbot v. Hawn, 346 U.S. 406, 1954 A.M.C. 1 (1953).

223 English translation, 6 BENEdict, AdMIRALTy 4 (6th ed. 1940). The Convention provides, so far as pertinent:

"Art. 2. If the collision is accidental, if it is caused by force majeure, or if the causes of the collision are in doubt, the damages shall be borne by those who have suffered them.

"This provision shall be applicable notwithstanding the fact that the vessels, or any one of them, may be at anchor (or otherwise made fast) at the time of the casualty.

"....

"Art. 4. If two or more vessels are in fault the liability of each vessel shall be in proportion to the degree of the faults respectively committed. Provided that if, having regard to the circumstances, it is not possible to establish the degree of the respective faults, or if it appears that the faults are equal, the liability shall be apportioned equally.

"The damages caused either to the vessels, or to their cargoes, or to the effects or other property of the crews, passengers, or other persons on board, shall be borne by the veseels in fault in the above proportion without joint and several liability toward third parties.

"In respect of damages caused by death or personal injury, the vessels in fault shall be jointly as well as severally liable to third parties, without prejudice to the right of recourse of the vessel with has paid a larger part than that which in accordance with tbe provisions of the first paragraph of this article she ought ultimately to bear.

"It is left to the law of eacl country to determine, as regards such recourse, the scope and effect of any legal or contractual provisions which limit the liability of the owners of a vessel toward persons on board.

"....

"Art. 13. This Convention shall extend to the making good of damages whicl a vessel has caused to another vessel, or to persons or things on board either vessel, either by the execution or nonexecution of a manoeuvre or by the nonobservance of the regulations, even if no collision has actually taken place."

2246 BENEDICT, ADMIRALTY 4 (6th ed. 1940). 
vessel to another or the persons or property aboard her when there is mutual fault; (2) that it is not available in cases of inevitable accident or inscrutable fault; (3) that damages are apportioned according to degree of fault if possible and, if not, then equally; (4) that both vessels are liable jointly and severally for death and personal injury but only severally for property damage; and (5) that a vessel which pays more than her share has a right to sue over for contribution. With definite exceptions as to unequal apportionment of damages and the lack of joint liability for property damage, and a possible exception as to inscrutable fault, the law of the rest of the world on this subject agrees with the practice in the United States.

Lacking a federal system, most foreign nations do not have our dual system of law. Their maritime and non-maritime laws have developed together and, except when the maritime law is regulated by international agreement, are expressed in the same statutes of general application. Especially is this so in the vast domains of the civil law from which admiralty law sprang and of which it is a part; in these countries admiralty has never been a separate system or body of law. Thus it is the general rule in civil law countries that contribution may be had and that, where the injured party's negligence contributes to his injuries, the parties divide the damages either proportionally or equally. This is true under the codes of France, ${ }^{225}$ Germany, ${ }^{226}$ and Japan, ${ }^{227}$ and the statutes of Norway, ${ }^{228}$ and is understood to be the common law of Sweden and Denmark. ${ }^{229}$ It may safely be taken as the general rule.

In Britain and her dominions, until recent years, contribution was not available and contributory negligence was a complete defense under the rules of the common law. In the United Kingdom contribution was enacted in $1935^{230}$ and proportional damages in $1945 .{ }^{231}$ While the Province of Quebec, where civil law prevails, divides damages without benefit of statute, ${ }^{232}$ the remainder of the Canadian provinces do so by statute, ${ }^{233}$

225 FRENCH Crv. CODE \$\$ 1382, 1383 (1804).

226 Geraran Civ. Code $\$ 254$ (1896).

227 JAPANESE Crv. Code, arts. 719, 722. The author is indebted to Alexander D. Calhoun, Jr., Esq., of the San Francisco and Tokyo bars, for information on the Japanese law. Letter from Alexander D. Calhoun to the author, April 12, 1956.

228 Introductory Act to tee Criminal Code, May 22, 1902, No. 11, \$\$ 25, 26.

229 The author is indebted to Hoyesterettsadvokat Per Gram, Oslo, for information on the Swedish as well as the Norwegian law and to Landsretssagforer Esben Dragsted for information on Danish law. Letters from Høyesterettsadvokat Per Gram to the author, April 12 and June 10, 1955, and from Landsretssagforrer Esben Dragsted, April 26, 1956.

$230 \mathrm{Law}$ Reform (Married Women and Tortfeasors) Act, 25 \& 26 GEo. 5, c. 30 (1935).

${ }^{231}$ Law Reform (Contributory Negligence) Act, 8 \& 9 GEo. 6, c. 28 (1945).

${ }^{232}$ Nichols Clemical Co. v. LeFebvre, 42 Can. Sup. Ct. 402 (1909) ; Canadian Pacific Ry. v. Frecliette, 24 Queb. K.B. 459 (1915).

233 Arberta Rev. Stat. C. 116 (1942); Brtr. Cor. Rev. Stat. c. 52 (1936), amended by Rev. Stat. c. 68 (1948); Rev. Stat. Mav. c. 215 (1940); New Br. Rev. Stat. c. 143 (1927); Nov. Sc. Stat. c. 3 (1926); Ont. Rev. Stat. c. 115 (1937); P.E. I. Stat. c. 5 (1938); SaSK. StaT. c. 23 (1944). 
as do New Zealand ${ }^{234}$ and at least one of the Australian provinces. ${ }^{235} \mathrm{At}$ least five of the Canadian provinces also provide for contribution. ${ }^{230}$

With the exception of claims, mainly for death, having their actual foundation in state statutes, the substantive law of the states and territories of the United States are not permitted to govern maritime claims. It may, however, be useful to glance at the laws of the states and territories for comparative purposes. Initially, in nearly all the states and territories the rules of the common law as to contribution and contributory negligence prevailed. Today in two of the states contribution seems to be provided without statute, ${ }^{237}$ and in at least seventeen more states and territories it is provided on various terms by statute. ${ }^{238}$ Proportional damages has not made such headway in the states as contribution has. Only two states have it as a rule of general application, ${ }^{230}$ but a number of others have adopted it in special applications and the movement for general adoption gains force, with new bills being regularly pressed in the legislatures. ${ }^{240}$

From this brief review of the law in other jurisdictions we may fairly state that contribution is the prevailing rule in the western world and that proportional damages runs only a hittle behind and promises to catch up. It is strange, therefore, to suggest that contribution is anything less than general in admiralty, a system which with the rest of the civil law has led the way in reform of the common law in these particulars. Equally strange is the anomalous adherence of the admiralty in America to the rule of equal division in collision cases after its own invention of proportional damages has been widely adopted elsewhere.

\section{IV}

\section{PROPORTIONAL DAMAGES}

The great anomaly of the maritime law applied in America today is the rule of equal division of damages in collision cases of mutual fault. ${ }^{241}$

\footnotetext{
234 NEW ZEAT. STAT. Nos. 3,29 (1947).

235 W. Aust. Stat. No. 23 (1947).

230 Alberta, British Columbia, Manitoba, Ontario, Saskatchewan. See note 233 sutpra.

237 Duluth, M. \& N. Ry. v. McCarthy, 183 Minn. 414, 236 N.W. 766 (1931) ; Zurn v. Whatley, 213 Wis. 365,251 N.W. 435 (1933).

238 Alaska CoMmp. Laws AnN. § 55-9-92 (1949); ARk. Stat. \$§ 34-1001 to -1009 (1947); Det. Code Anv. tit. 10, §§ 6301-02 (1953); GA. Code § 105-2012 (1933); Haw. Rev. Laws $\S \S 10487-93$ (1945); Ky. REv. Stat. $\$ 412.030$ (1953); LA. CIv. CoDE ANN. arts. 2103, 2161 (Dart 1945) ; MD. ANN. Code art. 50, \$§ 20-29 (1951); MICH. CoMp. LAWs $\$ 691.561$ (1948); Mo. Rev. Stat. $\$ 537.060$ (1949) ; N.J. Stat. ANN. $\$ \S 2 A: 53 A-1$ to -5 (1952) ; N.Y. Civ. Prac. Act § 211 a (1942) ; N.C. Gen. Stat. \$ 1-240 (1953) ; PA. Stat. ANn. tit. 12, \$\$ 2082-89 (Purdon Supp. 1954); R.I. Gen. Laws 1940, c. 940; TeX. Rev. Civ. StaT. art. 2212 (1948); VA. Code ANN. \& 8-627 (1950).

238 Mrss. Code ANN. $\S 1454$ (1942); Wis. Stat. $\$ 331.045$ (1949) (limited to personal mjury).

${ }^{240}$ See generally Prosser, Comparative Negligence, 41 Carrf. L. REv. 1 (1953).

241 The inflexibility of the rule is somewhat modified by the major-nnimor fault rule discussed in note 242 infra.
} 
This rule, as we have seen, has been abandoned in favor of proportional damages by the rest of the world and by the United States itself in personal injury and death cases, the bulk of contemporary maritime litigation. The courts, trying to choose between the injustice of equal division and the injustice of the "major-minor fault" exception, ${ }^{242}$ chafe discontentedly under the equal division rule in the belief that there is nothing they can do about it.

The Court of Appeals for the Second Circuit, in particular, is given to complaining regularly about the rule but is of the opinion that only the Supreme Court or Congress can initiate any change. ${ }^{243}$ In two recent cases, the Eastern and Southern districts of New York apportioned collision damages unequally according to fault and then, on rehearings, felt compelled to conform to the 50-50 rule. ${ }^{244}$ The Third Circuit actually went so

242 It frequently happens that the court finds equal division hard and unjust and yet is unable, in the state of the record, to overlook entirely the existence of fault in the comparatively innocent party. To meet this situation, two versions of the major-minor fault rule appear as an exception to the general rule of equal division in inutual fault cases.

Griffin says that the major-minor fault rule is expressed in three ways: (1) doubt is resolved in favor of minor offenders; (2) shight fault is held not contributing; and (3) shight fault is disregarded. Grifrin, Coltision 505 (1949). We are not concerned with the second expression since there is a finding of no causation and therefore no fault to be excused.

The major-minor fault rule was suggested as early as 1836 . The States Rights, 20 Fed. Cas. 201, 209, No. 11540 (E.D. Pa. 1836) (dictum). It now may be said that where there is a great disparity of fault the court may (1) resolve any doubt in favor of the minor offender, The Victory, 168 U.S. 410, 423 (1897); The City of New York, 147 U.S. 72, 85 (1893); or (2) actually excuse a recognized fault of the minor offender, The Great Republic, 90 U.S. (23 Wall.) 20, 34 (1874); The Dousman, 29 Fed. Cas. 180, 181, No. 17153 (C.C.D. IIl. 1854).

Occasional language in the cases should not lead one to beheve that there is any refusal to examine the conduct of one vessel whenever the faults of the other have been shown sufficiently egregious. The rule is simply one for mitigating a division of damages entirely disproportionate to fault in cases where the proportion of fault is unquestionably much nearer to sole fault than to equal fault. A review of major-minor fault cases will suggest that the minor faults excused are generally no less serious than faults which have condemned ships in other cases. However, the faults of the losing ships have usually been comparatively serious and the emphasis should probably be placed on "major." A favorite statement of the rule is that where a vessel's faults are very serious so as to account for the collision by themselves she will not be heard to cast doubt on the navigation of the other ship. See The Oregon, 158 U.S. 186 (1895); The City of New York, supra. In some cases the rule is used as a hedge by courts which have already determined that no fault was committed by one vessel. See GrIFrin, Collision 508 (1949). These, of course, are not true inajor-minor fault cases.

The courts have so much travail in attempting to determine what is sufficiently minor or major and are so often reversed on this point that it is surprising that proportional damages has not made more headway.

243 See, e.g., The Melrose, 237 F.2d 884, 1957 A.M.C. 64 (2d Cir. 1956), cert. denied, 352 U.S. 971 (1957); The Ruth, 231 F.2d 319, 1956 A.M.C. 823 (2d Cir.); Ahlgren v. Red Star Towing \& Transp. Co., 214 F.2d 618, 1954 A.M.C. 1504 (2d Cir.).

244 The Ruth, 135 F. Supp. 371, 1955 A.M.C. 1770 (E.D.N.Y.), aff'd, 231 F.2d 319, 1956 A.M.C. 823 (2d Cir.) ; The Melrose, 125 F. Supp. 110, 1955 A.M.C. 2012 (S.D.N.Y.1954), aff'd, 237 F.2d 884, 1957 A.M.C. 64 (2d Cir. 1956), cert. denied, 352 U.S. 971 (1957) (excellent discussion of problem in district court opimion). Both cases were affirmed with regrets about equal division. 
far in one case $\mathrm{e}^{245}$ as to modify a half damage decree to a $25 \%-75 \%$ apportionment and then, experiencing, as it said, "a growing doubt, not as to its power to make the order apportioning damages, but as to its conduct in not literally and respectfully following the moiety rule," ${ }^{246}$ on its own motion ordered a rehearing and restored the half-damage decree.

Before all this soul-searching there were in fact a number of precedents for unequal division in collision and similar cases. In 1874 the District Court for the Eastern District of Virginia was of the opimon that it could apportion unequally in collision cases if the facts warranted: ${ }^{247}$

Where there has been fault on both sides, the loss is divided; but whether equally or unequally, will depend upon the equities of each case.

In 1884 damages were apportioned $3 / 4-\pi / 4$ in the Southern District of Alabama in a collision case. ${ }^{248}$ In 1901 the Eastern District of New York apportioned $2 / 3-1 / 3$ in a case of scows breaking loose from inadequate moorings. ${ }^{249}$ And in 1952 the District of New Jersey apportioned 2/3-1/3 in a case in which a tug sank at a wharf. ${ }^{250}$ In addition Griffin reports that unequal division has been made in some unreported collision cases. ${ }^{251}$

These cases of unequal division indicate perhaps that the trial court may divide with impunity if it wishes. Far more significant than these precedents is the doctrine of the Supreme Court, now often lost from sight, that damages in admiralty are given or withheld upon enlarged principles of justice and equity and are within the sound discretion of the court. ${ }^{262}$ This rule was used by the lower courts in the early cases of unequal apportionment in personal injury, ${ }^{253}$ and it was this rule which was invoked and restated by the Supreme Court in The Max Morris, the case which effectively opened the door to unequal division in personal injury cases.

Even if we did not conclude that the general maritime law today calls for proportional damages in collision cases, it is hard to see how a district court, armed with the principle that damages are discretionary, could be held in error in apportioning where the unequal degrees of fault can be evaluated. The Supreme Court has never said that damages may not be

245 The Margaret, 30 F.2d 923, 1929 A.M.C. I (3d Cir.), cert. denied, 279 U.S. 862 (1929).

24630 F.2d at 928,1929 A.M.C. at 307-08.

247 The J.W. Everman, 14 Fed. Cas. 64, 66, No. 7591 (E.D. Va. 1874); see also Hudson

v. Pittsburgh Plate Glass Co., 263 Fed. 730, 733 (W.D. Pa. 1911).

248 The Mary Ida, 20 Fed. 741 (S.D. Ala. 1884).

249 The No. 6-H, 108 Fed. 429 (E.D.N.Y. 1901).

250 The William J. Tracy, 105 F. Supp. 910, 1952 A.M.C. 2017 (D.N.J.).

251 GRIFFIN, Coltision 564 (1949).

252 The Marianna Flora, 24 U.S. (11 Wheat.) 1 (1826); The Palmyra, 25 U.S. (12 Wheat.) 1 (1827).

${ }^{253}$ The Explorer, 20 Fed. 135 (C.C.E.D.La. 1884); The Wanderer, 20 Fed. 140 (C.C.E.D. La. 1884). 
apportioned unequally; it has simply sanctioned the application of equal division, the legal correctness of which can not be doubted and is not challenged here, but which is also in no way inconsistent with the application of unequal division by the lower court in a proper case. After all, it is to be remembered that when the Supreme Court first approved equal division, it relied upon the practice prevailing in the lower courts. ${ }^{254}$

But for the American exception in collision cases, almost the entire maritime world divides damages proportionally in every sort of maritime case. This would be true in America also, had the Brussels Collision Convention been ratified here. That it has not been ratified is not from opposition to proportional damages but from cargo opposition to provisions which would allow cargo to recover from each vessel only her proportional share of damages ${ }^{255}$ and from a poor translation of the Convention which resulted in a misunderstanding regarding the Convention's effect upon certain legal presumptions. ${ }^{256}$ The courts need not await the ratification of the Brussels Convention, a doubtful event, any more than they waited for statutory authority for proportional damages in personal injury cases. In the latter the lower courts ${ }^{257}$ led the way and the Supreme Court, ${ }^{258}$ and later Congress, ${ }^{250}$ followed.

The lament of the Second Circuit that it inust wait for the Supreme Court is the product of an unfortunate delusion. With a settled practice of equal division throughout the country, the Supreme Court is not going to grant certiorari to review that practice; ${ }^{260}$ in the rare collision case that reaches the Supreme Court today, the Court does not go far enough into the facts to make its own reapportionment of damages, to say nothing of the difficulty of a nine-judge court making such an apportionment. Just as in the personal injury cases in the last century, the place to inake a departure from the present illogical rule is in the district courts. If they exercise their discretion soundly, the courts of appeals must uphold them as they were upheld long ago in the personal injury cases. The resulting conflict in the circuits will bring the question promptly before the Supreme Court. Who, after acquaintance with the historical development of division of damages and pondering The Max Morris, can doubt that the decision of the Supreme Court will place the United States once again in step with the progress of the general maritine law?

254 The Catherine, 58 U.S. (17 How.) 169 (1854).

255 ROBINSON, ADMIRALTY 854 (1939).

256 See discussion in 4 BENEDICT, ADMIRALTY 262-69 (6th ed. 1940).

257 See text beginning at note 97 supra.

258 Ibid.

250 See notes 120 and 183 supra.

200 The inost recent denial of certiorari on this question was The Melrose, 352 U.S. 971 (1957). 
The present practice is a discredit to admiralty, which prides itself on its enlightened justice, flexibility, and equity and has formerly pointed out the path of progress to common law jurisdictions that today, in this vital matter, have overtaken and passed it. This is not the result of a lack of desire on the part of the admiralty judges but of the failure of the admiralty bench and bar to consult their history and to appreciate that, if they desire justice, they have only to do it.

\section{CONCLUSION}

Contribution, starting as a rude and comparatively narrow ancient doctrine, has gradually broadened to express refined notions of justice in many maritime situations. The product of this development may be expressed in a number of rules and observations for the guidance of courts and counsel:

1. Contribution, division of damages, and the reduction of damages on account of contributory negligence, however expressed, are all expressions of but a single right in admiralty, a right distinct from the right of contribution at law, not dependent on subrogation or any other equitable doctrine, and arising from the wrong itself.

2. The basic principle of contribution in admiralty is that where damages arise from the fault of two or more persons - including vessels as persons where liable in rem - such persons shall share responsibility for the damages.

3. Where a person at fault enjoys a statutory immunity from liability or where the liability is founded upon a statute which provides against contribution in the particular case, he does not, by virtue of the principle of contribution, share in liability for damages to other parties.

4. In all collision cases, with respect to all kinds of damages, and in other cases so far as only property damages is concerned, responsibility for the damage is usually shared equally.

5. Where personal injury and death are concerned, apart from collision cases, responsibility for the damage is shared in proportion to fault or, if the degree of such fault can not be determined, then equally.

6. Contribution applies to every kind of claim for delictual fault, willful, negligent, or statutory, except aggravated cases of willful fault.

7. Contribution applies to contractual claims based upon negligence, and despite contractual relations between contributors, unless the particular contract contemplates that the entire risk in the particular case be borne by one of the contracting parties.

8. Contribution applies where the damage results from mutual fault; where the damage results from fault on one side and on the other from unseaworthiness, failure to mitigate damages, or acquiescence in the risk 
in cases where that is allowed to have effect; or where the damage comprises unallocable successive damages from successive faults of different parties.

9. Contribution does not apply to cases of inevitable accident and probably no longer applies to cases of inscrutable fault.

10. Respecting in rem obligations, each vessel at fault shares in the damages without regard to common ownership. Where the owner is before the court though not all of his vessels at fault are, he nevertheless bears a share of the damages proportionate to the number of his vessels at fault.

11. So far as the pleadings properly set forth the claims, contribution may be recovered and completely adjusted in one suit in which all parties are before the court. Alternatively, it may be recovered by a later suit, provided that the total recovery of any party in successive suits may not exceed that which could have been recovered had all parties been before the court in a single suit.

12. In cases of damage to one party through the fault of two or more others, the innocent party may sue only one wrongdoer. If other wrongdoers are not brought in, the innocent party may have a decree for his entire damages. If more than one wrongdoer is before the court the entire damages must be appropriately divided among those actually present under a decree providing for payment by each of his share with a right over against the other or others for any portion of that share not collected.

13. Contribution is applied in limitation of liability cases before the Limitation Act is applied; a contribution claim may be made like any other claim in a limitation proceeding. This is so even though the claim is only contingent at the time; but the court may, on equitable grounds, deny any part of a claim for contribution which might be recovered elsewhere without depleting the limitation fund.

14. Parties may not realize a profit from dealings in claims for contribution.

15. Contribution is of the substance of the maritime law and inust be applied in every court.

16. The dictum in the Halcyon case quoted at the outset of this article is incorrect and the rule of the Halcyon case is limited to the situation there presented.

17. The trial courts and the courts of appeals, $m$ collision cases, are completely free to apportion damages unequally where the relative degrees of fault can be determined and in such cases should do so where it appears to be in the interest of justice. 


\section{California Law Review}

MEMMBER NATIONAT AND WESTERN CONFERENCES OF IAW REVIEWS

Published Five Times Yearly by Students of the School of Law of the University of California, Berkeley, California. Indexed in Index to Legal Periodicals and Public Affairs Information Service.

\begin{tabular}{ll} 
Subscription Price, $\$ 5.00$ & Current Single Copies, $\$ 1.50$ \\
\hline
\end{tabular}

\section{BOARD OF EDITORS}

Donato M. Camen Editor

Wallace R. Pect

Assistant Editor

WIIITAMR R. BERKMAN Managing Editor

GERAID R. KNECHT

ROBERT O. NAGLE

RoBert A. SEJIGSON

W. P. Crancex, Jr.

BIILY H. HUNT

DoNAID L. KING

MarsHatL W. KraUSE
MARC H. MONEEDSER

Article Editor

JoE J. YasakI

Book Review Editor

Revising Editors

Jomin E. Sparks

Stanton G. Ware

Associate Editors

HAROLD E. LANDIS

RICEARD T. LEMMON

Withaar O. Minor

ROGER J. NICHOLS

\section{MarILYN LINDQUTST \\ General Secretary}

\section{Contributors}

ARthud O. Armstrong, Jr.

MaIcolar S. BuRNSTETN

MTIEs A. Совb

Geörg Getger

Windiame L. Hugres
JOHN C. LEARX

Chardes A. Mituler

ShetDon C. St. Clatr

HoWARD M. WEISER 